Portland State University

PDXScholar

\title{
Examining the Popularity Concept in the Initial Public Offering (IPO) Market
}

Preston Rad

Portland State University

Follow this and additional works at: https://pdxscholar.library.pdx.edu/honorstheses

Part of the Finance Commons

Let us know how access to this document benefits you.

Recommended Citation

Rad, Preston, "Examining the Popularity Concept in the Initial Public Offering (IPO) Market" (2020).

University Honors Theses. Paper 886.

https://doi.org/10.15760/honors.907

This Thesis is brought to you for free and open access. It has been accepted for inclusion in University Honors Theses by an authorized administrator of PDXScholar. Please contact us if we can make this document more accessible: pdxscholar@pdx.edu. 
Examining the Popularity Concept in the Initial Public Offering (IPO) Market

\author{
by \\ Preston "Nima" Rad
}

An undergraduate honors thesis submitted in partial fulfillment of the requirements for the degree of

Bachelor of Science

in

University Honors

and

Business Administration: Finance

Thesis Adviser

Daniel Rogers, Ph.D., CFA, CAIA, FRM

Portland State University

2020 


\begin{abstract}
Popularity is the act of being liked. In Popularity: A Bridge Between Classical and Behavioral Finance, authors Roger Ibbotson, Thomas Idzorek, Paul Kaplan, and James Xiong (hereafter IIDX) explore the concept of Popularity in capital market theory. IIDX argue that certain companies have Popular characteristics that leads to overpricing caused by a Popularity premium. This paper begins with an overview of the historical methods of asset pricing, starting with the Capital Asset Pricing Model (CAPM). It progresses through the expansion of the model by financial theorists such as Eugene Fama and Kenneth French. Jay Ritter (1991) has documented the short-term overpricing and long-term underpricing phenomenon's in the Initial Public Offering (IPO) market. However, the explanation for this anomaly is widely up for debate. After evaluating the prior theories, this paper argues a new explanation: short-term underpricing and long-term overpricing are a result of Popular characteristics in IPO firms. A set of twelve IPO firms across three different time periods are examined for their first-day "pop" return, along with their proceeding longterm returns. While the results of this study are inconclusive, evidence is found that Popularity may cause these short-term underpricing followed by long-term overpricing in the IPO market.
\end{abstract}

Keywords: Popularity, Initial Public Offering, Behavioral Finance, PAPM, CAPM, Hot Issue Markets, Classical Finance 


\section{CONTENTS}

ABSTRACT

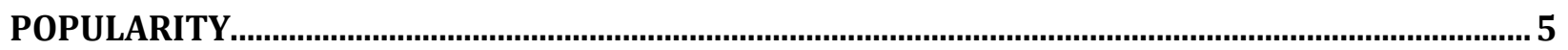

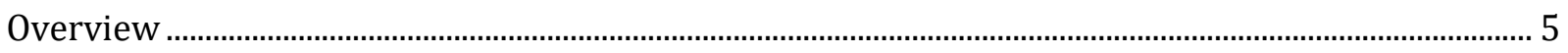

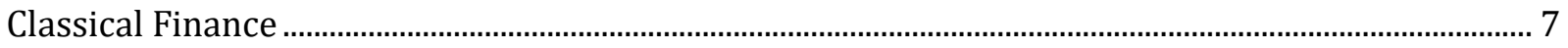

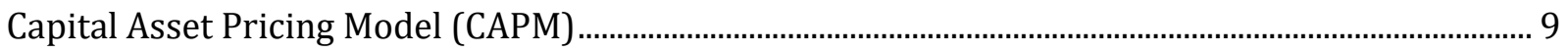

Fama-French Three-Factor Model................................................................................................................

Net Equilibrium Theory (NET) ………………................................................................................. 15

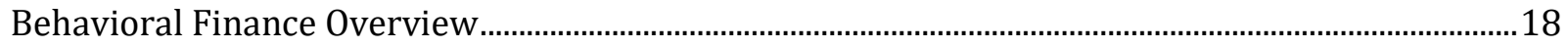

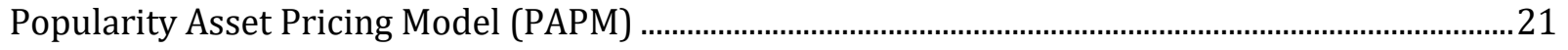

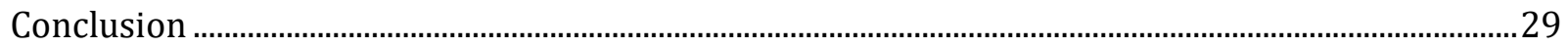

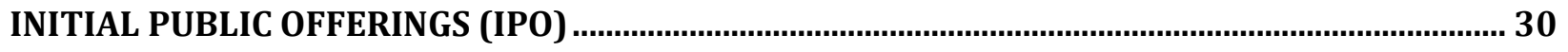

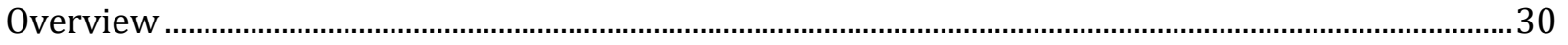

Short-Term Underpricing Phenomenon ............................................................................................... 31

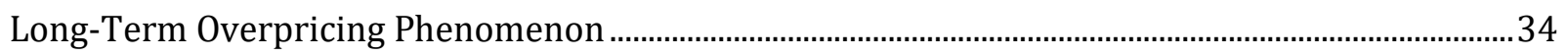

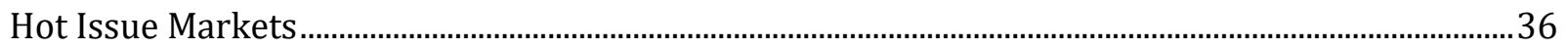

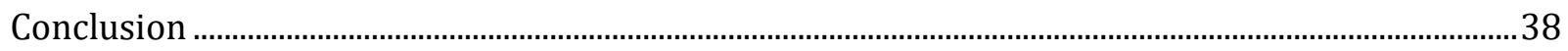

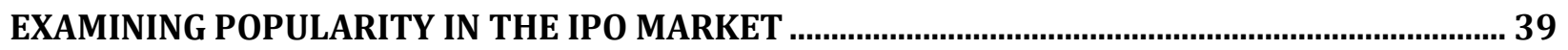

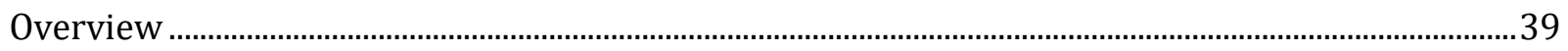

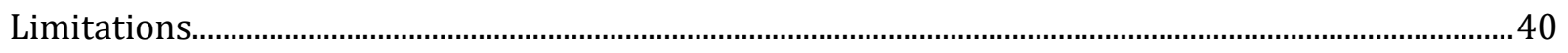

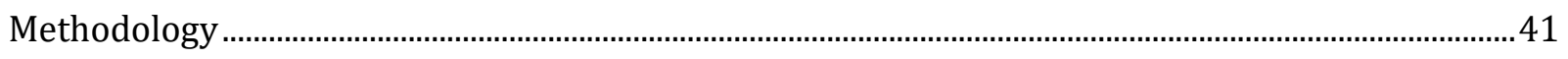

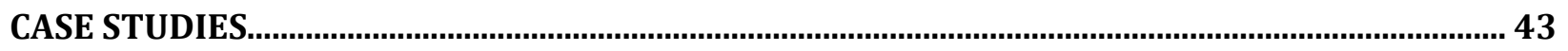

\#1 - Amazon.com (AMZN) .................................................................................................................. 43

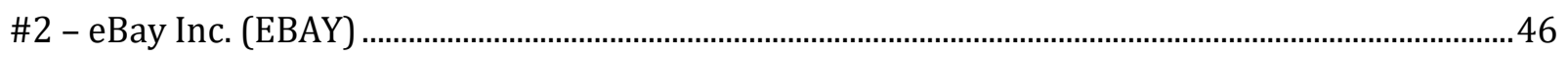

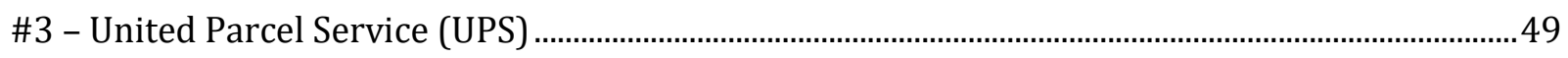

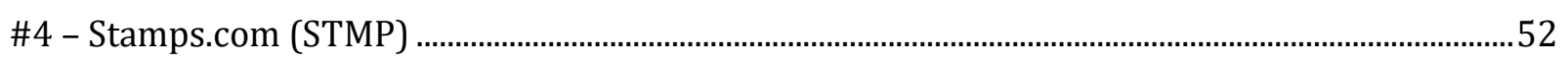

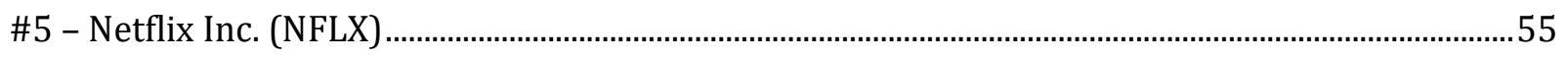

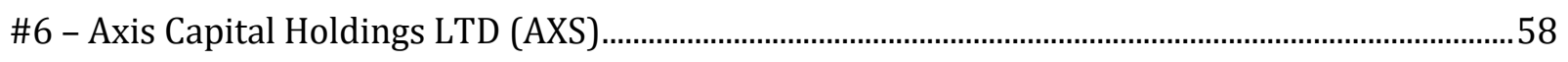

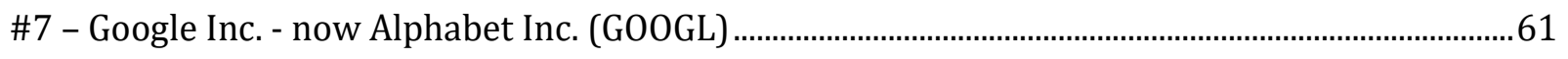

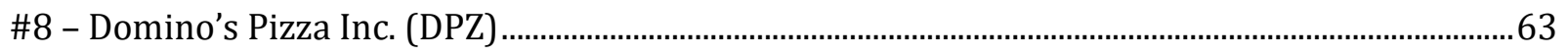

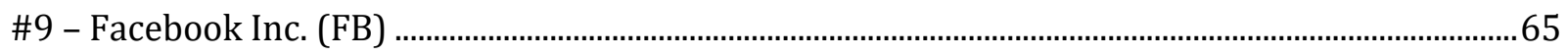

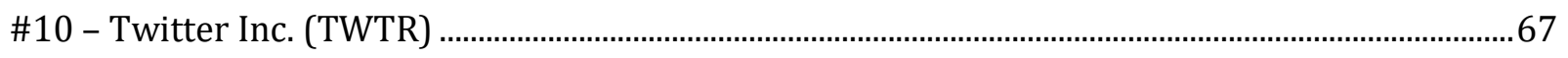

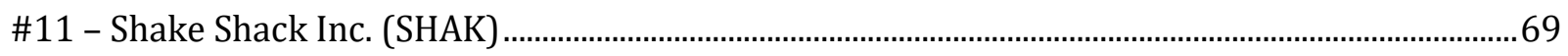




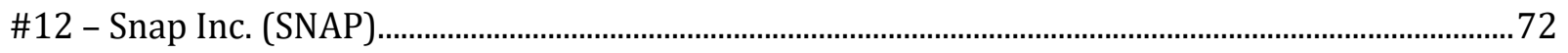

CONCLUSION

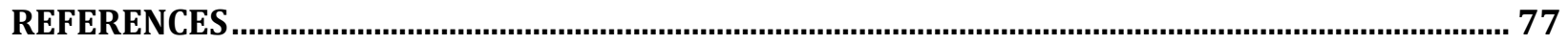

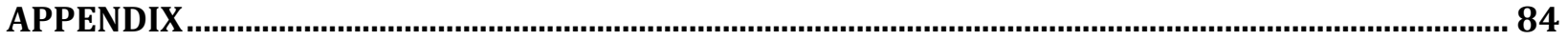

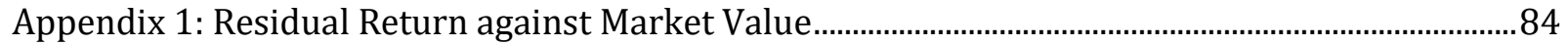

Appendix 2: Real Stock Prices and Present Values of Subsequent Real Dividends (annual data)..85

Appendix 3: Popularity-Based Explanations of Premiums and Anomalies............................................86

Appendix 4: Growth of \$1 for Equally Weighted Quartiles Based on Interbrand's BV Rankings,

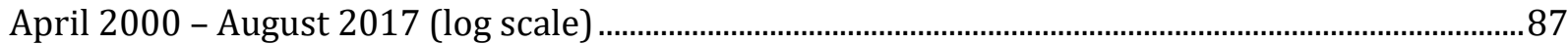

Appendix 5: Growth of $\$ 1$ for the Three Equally Weighted Portfolios Based on Morningstar Economic Moat Ratings, July 2002 - August 2017 (log scale) ................................................................. 88

Appendix 6: Growth of $\$ 1$ for the Equally Weighted Quartile Portfolios Based on Harris Poll RQs, April 2000 - August 3028 (Log Scale) . 89

Appendix 7: Growth of $\$ 1$ for Equally Weighted Quartile Portfolios Based on Coskewness, January 1996 - August 2017 (log scale) . .90 


\section{POPULARITY}

\section{Overview}

Popularity is a phrase first coined by Roger Ibbotson and Thomas Idzorek in 2014 in their article "Dimensions of Popularity." They describe it as another word for demand, and that different securities contain more favorable characteristics toward investors. This is a relatively new financial theory, and many have come before it. This section will discuss work that authors Roger Ibbotson, Thomas Idzorek, Paul Kaplan, and James Xiong (hereafter, IIKX) have done in their 2018 book Popularity: A Bridge between Classical and Behavioral Finance.

The Popularity concept combines concepts from both the classical and behavioral aspects of financial theory. The classical characteristics can be summarized by risks, which include any frictions that would drive a rational investor to be averse from particular securities, such as catastrophic events. The second is frictional characteristics of a security, such as taxes, trading costs, and asset divisibility. The attributes of behavioral finance include psychological impacts, which include preliminary biases such as purchasing a stock because it has a low impact on climate change. Another is cognitive errors that investors make when they misinterpret information of a stock, such as overvaluing a brand's value that is already built into the market price.

This section begins with an overview of classical finance, followed by the explanation of the Capital Asset Pricing Model (CAPM), the Fama-French Three-Factor model, and the Net Equilibrium theory. Following this is a summary of behavioral finance, and this section concludes with a study of the Popularity Asset Pricing Model (PAPM). The 
goal of this section is to set a foundational background of the theories and models that the PAPM expands upon and allow for more context in the case studies. 


\section{Classical Finance}

Under traditional financial theory, analysts and scholars operate under the assumption that all investors are both rational and fully informed. This includes the idea that investors focus solely on the risk and expected return of an asset, and that any preliminary biases held by an investor will be quickly arbitraged out of the market. Classical Finance is consistent with the Efficient Markets Hypothesis (EMH). There are four basic principles in classical finance: rationality, risk-free arbitrage, equilibrium, and efficient markets (IIKX 2018).

- Rationality: The principle that all investors use logical decision-making to determine the price of an asset, such as cash flows, expected return, and risk. Characteristics such as liquidity and tax efficiency are assumed away due to the non-risk aspects of investments.

- Risk-free arbitrage: The "law of one price." It assumes that subtracting transaction costs, any two assets with the same value, should have the same price.

- Equilibrium: The assumption that "supply equals demand." This means that investors are currently holding the exact amount of the security they desire at the specified price. Frictionless equilibrium assumes no transaction costs, and therefore there are no opportunities for a risk-free arbitrage.

- Efficient Capital Markets Theory: Written about by Eugene Fama in 1970 and is described as "prices 'fully reflect' available information" (Fama 1970). That said, Fama also notes that "fully reflect" is a loose term, and to be able to test whether a 
market is efficient, this hypothesis must have a different model to explain this parity.

In classical finance, most models assume rationality and efficient markets. The main difference is risk-free arbitrage versus equilibrium. Models such as the Arbitrage Pricing Theory (APT) (Ross 1976), along with the Black-Scholes option pricing model (Black and Scholes 1973), assume risk-free arbitrage opportunities and the possibility of finding two assets with an equal payout but different price. The next sections will look at the equilibrium-based Capital Asset Pricing Model (CAPM) and the Fama-French Three-Factor Model. An overview of Behavioral Finance will proceed before summaries of New Equilibrium Theory (NET), and finally, the Popularity Asset Pricing Model (PAPM). 


\section{Capital Asset Pricing Model (CAPM)}

\section{Background}

The most well-known classical finance equilibrium model is the Capital Asset Pricing Model (CAPM), first written about by William Sharpe (1964) and John Lintner (1965). This model has been widely used to assess both the cost of capital for firms and evaluating management portfolios. The model bears intuitive and straightforward characteristics of asset pricing that can be widely applied, with the underlying observation that the relationship between risk and return is linear. It operates under four key assumptions - that individual investors are price takers, there is a single-period investment horizon, investments are limited to traded financial assets, and that there are no taxes or transaction costs.

Another popular model before the CAPM was the dividend discount model (DDM) (Gordon 1963). The DDM was a method of valuing a company's stock prices based on the theory that it is worth the sum of all future dividend payments, discounted back to its present value. This model presented advantages in the way of a simple justification and no subjectivity - in other words, there is no ambiguity in the DDM. On the other hand, it fails to recognize systematic risk (beta), which limits its use in the real world. Beta is an important variable because it cannot be observed and, therefore, cannot be completely mitigated.

The CAPM adds to the model of portfolio choice, often called the mean-variance model, developed by Harry Markowitz (1959). This model assumes the requirements of classical finance where investors are risk-averse, and that they care only about the mean and variance of their one-period investment. As a result, investors select a "mean-varianceefficient" portfolio, which is the portfolio with the lowest deviation, and the highest 
expected return. Building on this, Sharpe (1964) and Lintner (1965) add two assumptions to the Markowitz model; The first is that all investors choose one specific market rate, and the second is that there is a risk-free rate, which is also the same for all investors in the market.

The CAPM formula: $R_{a}=R_{r f}+\beta_{a} X\left(R_{m}-R_{r f}\right)$, where:

- $R_{a}=$ Expected return on a security.

- $R_{r f}=$ Risk-free rate.

- $R_{m}=$ Expected return of the market.

- $\beta_{a}=$ The beta of the security.

\section{Strengths}

One of the strengths of the CAPM is its ease of use due to the simplicity of the model. Given only four variables, it is relatively simple to obtain a working required return for given securities. Another advantage of the CAPM is that, contrary to existing models, the variable beta accounts for systematic market risk. It also assumes that investors hold a diversified portfolio, eliminating the need for a variable of unsystematic (company/industry-specific) risk.

\section{Shortcomings}

The most significant shortcoming in the model is the difficulty in conducting a valid test of the model (Fama and French 2004). For example, the CAPM states that the risk of the security/portfolio must be measured against a relative "market portfolio." However, the process of determining a market rate for the portfolio is widely up for debate. There are many interpretations as to what constitutes an assets' "market portfolio," as one could 
include consumer durables, real estate, and human capital, in addition to financial assets. Additionally, whether to use the United States common stocks or instead use a worldwide market portfolio will also differ the expected return of an asset. Fama and French were critics of the model because the assumption of one single risk factor limits the usefulness of this model. They found that, on average, only about $70 \%$ of a portfolio's return is explained by its beta (Fama and French 1922).

\section{Conclusion}

While the CAPM offers a simplistic way to value single-security and portfolio returns, there are drawbacks in the model that make it far from being applicable in the real-world. These are the assumptions involved in determining key variables such as riskfree rate, market risk premium, and beta. However, Fama and French expanded the CAPM to include two new variables with their three-factor model shown below. 


\section{Fama-French Three-Factor Model}

\section{Background}

The Fama-French Three-Factor model (Fama and French 1992) attempts further to determine the required rates of return for a given asset. Fama and French add two new variables to the existing CAPM formula stemming from observations about the relationship between portfolio returns and market value (size) (Banz 1980), and book-market ratios (value) (Bhandari 1988).

In 1980, Rolf Banz published a paper to the Journal of Financial Economics that displayed an empirical relationship between return and total market value of common stocks, specifically in the New York Stock Exchange (NYSE). The core thesis of this observation is that smaller firms have historically higher risk-adjusted returns compared to larger firms, on average. That said, this effect is not linear in market value; the main impact is when comparing tiny firms to large firms, while there is little difference between average-sized firms and large firms. In conducting his empirical test, Banz's sample was all stocks quoted on the NYSE for at least five years between 1926-1975. See Appendix 1 for the results of this study.

The second factor in Fama and French's model comes from Bhandari's 1988 study evaluating book-market returns. In this study, a positive correlation between stock returns and the debt-ratio was discovered after controlling for both beta and firm size. While some may argue that debt-ratio is simply a proxy for risk, the relationship was determined to be insensitive to variations in market proxy or estimation technique (Bhandari 1988). The inclusion of these two concepts led to new variables added to the CAPM formula, size (SMB), and value (HML). 
The Fama-French 3-Factor model: $R_{a}=R_{r f}+\beta_{a} X\left(R_{m}-R_{r f}\right)+\beta_{S M B}+\beta_{H M L}$, where:

- $\quad \beta_{S M B}=$ return spread of small minus big (SMB) stocks, otherwise known as the size effect.

- $\quad \beta_{H M L}=$ return spread of high minus low (HML) stocks, otherwise known as the value effect.

\section{Strengths}

Like the CAPM, a strength of the Fama-French model is its ease of use. At the same time, it effectively applies two new variables to determine the expected return for an asset. While the CAPM's beta is only able to explain an average of 70\% of a portfolio's beta, Fama and French (1992) claim that their three-factor model can explain up to 95\% of returns for a cross-section of equity portfolios of various sizes and styles. This implies that the FamaFrench Three-Factor model is more effective in estimating returns for securities than the existing CAPM.

\section{Shortcomings}

Problems in this model again include the inability to conduct valid tests given the same shortcomings of the CAPM. Additionally, critics argue that HMB and SMB simply capture the same risks associated with a beta, or that these are simply persistent mistakes made by investors and they do not hold any valid correlations to the return. Fama and French published a paper in 1996 in which they discuss a five-factor model, "Multifactor Explanations of Asset Pricing Anomalies." In it, they reveal that their "main 
embarrassment" of the three-factor model is that they fail to capture the continuation of short-term momentum anomalies.

\section{Conclusion}

Fama-French Three-Factor model does an excellent job of providing two new valid variables to the CAPM. Still, it lacks the complexity of a model that can be used effectively in practice. In the next section, Ibbotson, Diermeier, and Siegel (hereafter, IDS) further build on the core CAPM model in their New Equilibrium Theory (NET). 


\section{Net Equilibrium Theory (NET)}

\section{Background}

IDS constructed their paper in 1984. The main idea of the framework is, "[the more] Investors demand an asset, the more desirable the asset's characteristics" (IDS 1984). In both the CAPM and Fama-French Three-Factor model, this relates to investors desiring an asset that has more favorable risk characteristics. However, these models both assume only costs that are associated with risk. In the NET, however, IDS expand the previous models by including costs associated from all sources - including "various risks, as well as taxability, marketability and information costs - affecting all assets in an investor's opportunity set - stocks, bonds, real estate, human capital, venture capital, tangibles and intangibles" (IDS 1984).

NET does not include a mathematical pricing equation or an analysis of each cost. Instead, it uses supply and demand graphical analysis to determine the validity of the theory. Instead of viewing supply and demand in terms of demand for capital, they evaluate their argument in terms of supply and demand for capital market returns. While all investors should have the same proposed preferences in terms of risk and risk-aversion, which translates into the same before-cost expected return, investors individually determine the price of additional costs, otherwise known as frictional factors. The demand curves they present reveals investor preferences for tangible items such as more liquidity, less taxation, and so on (IDS 1984).

In Popularity: A Bridge Between Classical and Behavioral Finance, IIKX (2018) expand upon this theory to provide a formal economic model, while further explaining IDS' idea mathematically instead of using supply and demand graphical analysis. In their model, 
IIKX build on the rational models of both the CAPM and Fama-French Three-Factor to include variables involving liquidity and risk anomalies. Higher liquidity is a favorable characteristic to investors, because the more liquid their asset, the more likely they are to be able to convert the asset into cash quickly. There are many frictional factors in the risk anomaly variable, including the following: information costs, search and transaction costs, divisibility costs, and miscellaneous factors.

- Information costs: The costs associated with gathering information on the value of a particular asset.

- Search and transaction costs: Items such as broker fees or agent commissions in completing a transaction.

- Divisibility costs: Associated with larger transactions such as real estate and venture capital investments, and indivisibility involves investors having to take on a high amount of residual risk to partake in an investment.

- Miscellaneous Factors: Other factors influencing costs include human capital, nonpecuniary costs or benefits, storage, maintenance, or anything else that could affect the cost of capital.

The NET formula modeled by IIKX: $R_{a}=R_{r f}+\beta_{a} X\left(R_{m}-R_{r f}\right)+\beta_{S M B}+\beta_{H M L}+\beta_{L I Q}+\beta_{R I S K A}$, where:

- $\beta_{\text {LIQ }}=$ Return-spread of liquidity for a particular security.

- $\beta_{\text {RISKA }}=$ Return-spread of risk anomalies for a particular security, given the factors above. 


\section{Strengths}

NET further progresses existing financial theory by adding non-risk related characteristics such as taxability, marketability, and information costs. With the inclusion

of frictional features, NET gets one step closer to formulating how investors think in terms of real-world preferences.

\section{Shortcomings}

This theory falls short because it does not include any financial modeling or mathematical equations for the characteristics mentioned (before IIKX's 2018 expansion of the argument). Additionally, it lacks behavioral characteristics of investors, which is another factor that influences investment decisions.

\section{Conclusion}

The NET does an excellent job expanding into frictional and non-risk characteristics of asset-based investor attitudes. However, IIKX (2018) reiterate that these are a subset of classical attributes, ignoring behavioral characteristics/biases. This next section will examine these specific biases and idiosyncrasies of behavioral finance that are often overlooked by financial models. 


\section{Behavioral Finance Overview}

\section{Background}

Since its inception in the 1980s, behavioral finance has attempted to explain biases, heuristics, and inefficiencies present in financial markets. The core idea of behavioral finance is that not all investors act rationally, and instead hold preliminary biases that influence investment decisions. In 2003, Robert Schiller published a paper to the Journal of Economic Perspectives detailing the progression of behavioral finance. In it, Schiller argues that the concept of efficient markets may work in theory, although there is ongoing evidence that not all investors behave rationally. Appendix 2 proves this assumption by showing how real stock prices vary significantly from the present values of subsequent real dividends.

\section{Smart Money vs. Ordinary Investors}

The theories in classical finance, particularly involving efficient capital markets, assumes that all investors are both rational and fully informed. However, this theory does not work in markets where investors make irrational investment decisions. The thesis behind why classical finance works are because "smart money" investors, or those who were rational and fully informed, could efficiently capitalize on arbitrage opportunities presented by uninformed, irrational "ordinary investors," which brings the market back to equilibrium. However, if this were the case, there would not be market bubbles like the tech crash in 2000 or the financial crash in 2008. There were bubbles in the market created by irrational preferences, which are explained through behavioral finance. 


\section{Cognitive Psychology}

While investors may behave irrationally for a variety of reasons, most involve biases that an investor may have. Cognitive biases refer to how an investor may think. Most include systematic errors, such as overconfidence or putting too much weight on recent experiences, among others (Ritter 2003). These preferences tend to create distortions (bubbles) in the market. The following is a shorthand list of some cognitive biases' investors face:

- Heuristics: Individuals investing for retirement typically allocate their funds using the $1 / N$ rule, where $N$ is the number of choices for how to invest retirement money. For example, if there are three funds, two being equity funds, investors will typically invest $2 / 3$ of their funds into stocks (Ritter 2003).

- Overconfidence: Investors tend to be overconfident in their ability to price stocks. This often leads to a lack of diversification among securities.

- Framing: This involves how particular investment decisions are presented to investors. For example, if someone sees that ground beef at a grocer is $80 \%$ lean, they will be more likely to purchase it than if it were presented as $20 \%$ fat.

- Representativeness: Investors tend to overweight short-term averages, based on having recent experience with it.

- Conservatism: Contrary to representativeness bias, conservatism is when an investor does not adjust to a short-term change in structure. However, once this change becomes a longer-term trend, they tend to overreact to this change, resulting in representativeness bias. 
- Disposition Effect: This refers to the anomaly where investors decide to avoid paper losses by holding their assets for longer durations than if they were to realize a paper gain. In an example from Jay Ritter (2003), if someone purchases a stock at $\$ 30$, which then drops to $\$ 22$ before rising to $\$ 28$, most people do not want to sell until the stock rises above $\$ 30$.

\section{Supply and Demand Imbalances}

Other factors that may influence misvaluations come from temporary imbalances in supply and demand. An example of this is the increased usage of index funds (Ritter 2003). Index funds force a demand shift because an asset's demand is no longer relative to an increase in expected future cash flows. Classical finance would point to arbitrageurs to take advantage of this imperfect market. However, the effect can be limited, given restrictions like short sales constraints, or "if there is no guarantee that the mispricing will be corrected within a reasonable timeframe" (Ritter 2003). 


\section{Popularity Asset Pricing Model (PAPM)}

\section{Popularity}

The Popularity concept is a culmination of the theories and models above into one, modeled by the Popularity Asset Pricing Model (PAPM). Popularity builds on classical finance and the NET, stating that investors prefer lower risk and frictional costs for their assets. It also includes aspects of behavioral finance, such as different characteristics and anomalies that investors prefer and are therefore Popular. For example, while risk is Unpopular, liquidity is Popular (Ibbotson and Idzorek 2014). Popularity can also help explain temporary market mispricings. The general thesis of this model is that the less Popular a security is (based on these characteristics/anomalies), the lower the expected price, resulting in a higher expected return.

In 2017, Ibbotson and Idzorek expanded upon their Popularity theory in their Popularity and Asset Pricing article. In it, they review well-known premiums and anomalies across classical and behavioral finance and evaluate if they are consistent with the idea of rewarding Unpopular characteristics with positive long-term premiums. These are listed below (refer to Appendix 3 for summarization of these characteristics/anomalies):

- The Equity Premium: Additional risks from equities compared to other assets such as bonds and risk-free rates implies that stocks are Unpopular from a risk perspective, and therefore offer a higher return. This is consistent with the CAPM.

- The Size Premium: First identified by Banz (1981) and shown in the Fama-French Three-Factor model, small-cap equities historically have higher returns than their large-cap peers. Ibbotson and Idzorek (2017) also mention that in addition to higher 
risk, small-cap stocks are less liquid and infrequently covered by analysts (resulting in higher research costs), which makes them Unpopular.

- The Value Premium: Fama and French use Bhandari's 1988 publication to show how companies with a higher book-market ratio, and therefore a higher value outperform growth stocks. Critics attribute this premium simply to risk characteristics, though the relationship is insensitive to variations in market proxy or estimation technique. Academics debate explanations for this premium, although Lakonishok, Shleifer, and Vishny (1994) argue, "the value premium (or glam stock discount) is the result of systematic suboptimal behavior of typical investors related to consistent overconfidence/overestimation of future growth of earnings." Growth stocks are considered Popular and value stocks Unpopular. The result is that growth stocks are relatively higher-priced than value stocks.

- Liquidity: In terms of classical finance, rational investors prefer an asset that is more liquid. Amihud and Mendelson have documented in their 1986 article that lessliquid stocks outperform more-liquid equities. This is in line with Popularity, showing that liquidity is Popular, but results in lower returns.

- Risk Anomalies: Ibbotson and Idzorek (2017) bundle severe downside risk premium along with the low volatility and low beta anomaly, citing that they work in different ways. Investors typically do not like stocks with severe downside risk (shown by more negative coskewness), according to Kraus and Litzenberger (1976). However, stocks with more negative coskewness yield a higher return. Therefore, the severe downside risk is Unpopular, which leads to a higher premium paid for stocks with lower negative coskewness. Looking at the low volatility and low beta anomaly, a 
publication by Baker, Bradley, and Wurger (2011) implies that active institutional investors intentionally seek a beta higher than one with hopes of outperforming the market. However, this typically results in a lower return. Investors preferring highbeta stocks means that lower beta and volatility are Unpopular despite an expected higher return for these equities, consistent with Popularity.

- Environmental, Social, and Governance (ESG): ESG is the difference between 'sin' stocks and socially responsible investing (SRI). Stocks with a higher ESG rating are typically more Popular to investors. Hong and Kacperzyk (2009) studied the returns of 'sin' stocks, finding that these equities produced a substantially higher annual alpha, arguing that sin stocks typically attract fewer institutional investors and thus have less analyst coverage. Higher returns in sin stocks mean that while investments with a more excellent ESG ranking tend to be more Popular, they yield lower returns.

- Competitive Advantage, Brand, and Firm Reputation (CABR): Stocks that hold more desirable attributes regarding competitive advantage, brand, and reputation, typically are more Popular (and therefore overpriced) in the market. This likely has to do with the ambiguity around pricing intangible assets such as brand.

- Momentum: Ibbotson and Idzorek (2017) refer to this anomaly as "consistent with mispricing, [where] past winners seem to continue to win for a period of time." An example of this could be a breaking news headline that captures the interest and attention of investors. While momentum can push a stock price higher in the short term, this is usually the result of biases from behavioral finance. Once the price hits a peak in price that cannot be justified by fundamentals, the price typically comes 
crashing down until the price can stabilize at a more justified level. Buying into momentum is Popular, despite the ensuing crash that usually occurs once the stock price exceeds its fundamental valuation.

\section{Assumptions and Conclusions of the PAPM}

In their 2018 publication, IIKX expands upon the existing Popularity concept to build a financial model for their discovery. In their model, they suggest that a market may be "beyond efficient," resulting in information that is irrelevant to securities reflected in the price due to behavior preferences (IIKX 2018). In this model, markets are beyond efficient, which leads to biased stock prices. A model that contains and allows for some investors to hold premiums that outperform the market, and for some investors to tilt away from these premiums, thus underperforming the market, is needed. Assumptions made by the PAPM are listed below, along with the conclusions of the model.

\section{Assumptions of the PAPM (excerpt from IIKX 2018):}

1. Each security has a bundle of characteristics.

2. Investors have preferences regarding these characteristics in addition to their preferences regarding risk and expected return.

3. All investors use a generalized form of mean-variance optimization that incorporates preferences regarding security characteristics.

4. All investors have the same forecasts; that is, they hold the same capital market assumptions (expected returns, standard deviations, and correlations).

5. All investors agree on what the characteristics of the securities are.

6. All investors can borrow and lend at the same risk-free rate without limit. 


\section{Conclusions of the PAPM (excerpt from IIKX 2018):}

1. The market portfolio does not maximize the Sharpe ratio among all portfolios of risk assets.

2. Each investor forms a customized portfolio of the risky asset that reflects his or her attitudes toward each security characteristic. This portfolio is combined with long or short positions in the risk-free asset. Portfolio optimization is required to find the overall investor-specific portfolio.

3. The expected excess return of each security is a linear function of its beta and its popularity loadings, which measure the popularity of the security based on its characteristics relative to those of the beta-adjusted market portfolio. The popularity loadings are multiplied by the popularity premiums, which are aggregations of the preferences of the investors regarding the characteristics. In this way, the market aggregates investor preferences in determining the influence of security characteristics on the expected returns and prices of the securities.

Source: Based on pages 62-63 in IIKX (2018).

\section{Empirical Evidence}

IIKX (2018) provide empirical evidence by examining the characteristics and anomalies of Popularity. Previous literature has not reviewed the aspects of brand value, competitive advantage, and company reputation. The final in-depth analysis in this section addresses the stock-specific characteristic; severe downside tail risk (Unpopular). 
IIKX (2018) consider four portfolios formed by splitting the investable universe of stocks equally among equally populated quartiles. Quartile 1 contains stocks with the most Popular attributes, while Quartile 4 contains stocks with the least Popular attributes. The authors note that while a mutually agreed-upon measure of a security's Popularity does not exist, they have identified unstudied characteristics that attempt to serve as proxies of Popularity. These proxies include:

- Interbrand's annual "Best Global Brands" report: Interbrand publishes a list annually of the top 100 brands with the highest estimated brand value.

- Morningstar's economic moat ratings: Morningstar's analysts use several factors to estimate a company's competitive advantage rating, then splits each company into having either a wide moat, narrow moat, or no moat. A company with a wide moat is Popular, while a company with no moat is Unpopular.

- Nielson's Harris Poll reputation quotient: This poll measures the reputation of a company by consumers through 20 attributes, which form their "reputation quotient." IIKX believes this proxy aligns well with the characteristics that investors seek.

\section{Brand Value}

IIKX (2018) use their quartile methodology along with Interbrand's brand value for the top 50 companies from 2000 to 2017. The growth of $\$ 1$ for each quartile is in Appendix 4. As shown, Quartile 4 (lowest brand value) far exceeds the return of the other three quartiles and is therefore consistent with the Popularity concept. 


\section{Competitive Advantage}

Using Morningstar's economic moat ratings of an average of 1,039 companies, IIKX (2018) discovered that, again consistent with Popularity, companies that had no economic moat from July 2002 - August 2017 had the highest level of returns. (Refer to Appendix 5).

\section{Reputation}

IIKX (2018), using Nielson's Harris Poll reputation quotient as a proxy to represent the reputation of a company, analyzed the reputation quotient for the top 40 and 50 firms in 2000 and 2017, respectively. In it, they find that the performance of companies in Quartile 4 has a higher return from April 2000 - August 2017, shown in Appendix 6.

\section{Tail Risk (Coskewness)}

Negative coskewness implies that a security will have more substantial losses than the market when a crash occurs. Subsequently, Kraus and Litzenberger (1976) found that investors dislike negative coskewness, therefore rendering it Unpopular. While modeling their study after the empirical analysis conducted by Harvey and Siddique (2000), IIKX (2018) chose to focus specifically on a 20-year period to evaluate premiums from securities with a negative coskewness.

Starting from January 1991, IIKX (2018) sorted the investable universe of US stocks into four quartiles based on their negative coskewness. Quartile 4 (most negative coskewness) yielded the highest return as a result of their study. To conclude, based on coskewness, IIKX's (2018) results are consistent with Popularity and inconsistent with the risk-return paradigm. See Appendix 7 for a chart of the returns from each quartile. 


\section{Other Characteristics/Anomalies}

IIKX (2018) also perform empirical analysis regarding the characteristics of lottery stocks, beta and volatility, size, value, liquidity, and momentum. Using ten factors to analyze these characteristics, they find that seven out of ten are consistent with Popularity. Still, only two are compatible with the classical framework of more risk resulting in higher returns. The three factors that were not consistent with Popularity - larger companies based on high assets, high revenue, or high net income - are believed to be coupled with market capitalization to form valuation ratios (IIKX 2018). This implies that investors are unable to agree on whether these characteristics are desirable or undesirable uniformly. Overall, while risk is typically Unpopular, IIKX (2018) note that risk can be Popular in certain circumstances - though it is likely these characteristics end up dominating the approximated returns in the stock market. 


\section{Conclusion}

This historical study of past theories shows how Popularity encapsulates the concepts from prior models of classical finance and presents the argument that these do not work in the real world. Popularity includes investor biases studied in behavioral finance that explain the anomalies. By laying out a set of characteristics to evaluate both risk and nonrisk characteristics of asset pricing, IIKX (2018) formulates the PAPM model. Empirical evidence then determines the viability of this model, as IIKX (2018) finds that the PAPM is consistent with the Popularity concept and that there is a negative return to Popularity with an associated premium for the favorable characteristics. In doing so, IIKX (2018) formulate a model that bridges the gap between classical and behavioral finance. The next section looks at anomalies and characteristics of the initial public offering (IPO) market. 


\section{INITIAL PUBLIC OFFERINGS (IPO)}

\section{Overview}

An initial public offering (IPO) is the event in which shares of a company sell to both institutional and retail investors in the public equity market. IPOs are typically underwritten by investment banks that arrange to list shares on a stock exchange. There have been extensive studies about pricing these offerings. Jay R. Ritter from the University of Illinois is one of the most well-known IPO pricing theorists. Pricing IPOs is extremely difficult because there is no "market price" before the listing, and most issuing companies have little to no operating history (Ibbotson, Sindelar, and Ritter 1994).

There are three main parties involved in the offering: the issuing company, the investment bank, and investors purchasing the offering. A problem in pricing IPOs is due to conflicting interests across each party involved. If the price is set too low, the issuing company may not get the full amount of capital to fund their business operations. However, if the price is too high, the investor may not get their required return to invest. Even worse, the investors will become unwilling to purchase IPOs from the investment bank if they have a history of overvaluing offerings. Therefore, it is the job of the investment bank to ensure that they fairly price the offering to satisfy all ends of the transaction.

The next section covers three anomalies in the IPO market. The first is the shortterm underpricing phenomenon, which typically results in high first-day returns for investors. The second is the long-term overpricing phenomenon, where IPOs tend to underperform the broader market in the long-term. Lastly, the "hot issue" market phenomenon will be examined, which takes place when irrational investing during specific hot market periods. 


\section{Short-Term Underpricing Phenomenon}

\section{Overview}

The average initial (first day) return of IPOs is estimated to be 16.4\% (Ritter 1991), indicating that initial public offerings are underpriced in the short-term. Financial theorists have attempted to examine an explanation for this phenomenon, although there is no clear answer. Instead, different theories provide a reason for this occurrence: “The Winner's Curse," dynamic information acquisition, information cascades, reducing legal liability, and enhancing banker relations with investors.

\section{The Winner's Curse}

One possible explanation for the sometimes-severe underpricing of IPOs is due to the "Winner's Curse" phenomenon. When a stock gets issued to the public exchange, typically, a fixed number of shares get sold at the offering price (Ibbotson, Sindelar, and Ritter 1994). In this scenario, investors are split into two distinct categories: completely informed and completely uninformed, referring to knowing the future stock price of an IPO. Due to the limit in supply on the number of new shares (owned by the informed investors), the uninformed investors will only be able to purchase a limited number of shares owned by the informed investors. This leads to the Winner's Curse because if the uninformed investors get all the shares they demand, it is a result of the informed investors not wanting those shares. Therefore, uninformed investors will only purchase the offering if it is sufficiently underpriced to compensate for this existing bias (Rock 1985).

\section{Dynamic Information Acquisition}

Another reason for investment bankers to underprice IPOs is to use the market of the uninformed investors to help determine the value of the offering, first written about by 
Lawrence Benveniste and Paul Spindt (1989). In the article they argue that underpricing is a natural consequence of the premarket auction due to the ambiguity surrounding a fair market price for a stock that has not yet been in the public market. Ibbotson, Sindelar, and Ritter (1994) agree with this phenomenon and argue that this technique is used by investment bankers to get regular investors to reveal their valuations. However, they mention that this is a "dynamic" model because investment bankers use an underpriced preliminary prospectus valuation to gauge the demand in the market, and then in the final prospectus, use their information gathered to make only a partial adjustment to the final offer price. Simply put, if the offer price of an IPO is revised upwards, it is likely more underpriced, rather than if it is revised downwards. They illustrate this with an example from Microsoft in which the preliminary prospectus contained an initial offering of \$16-19 per share, though the final offering price was $\$ 21$ per share. The stock ended up closing at $\$ 27.75$ on the first day of trading, producing a 32\% return (Ibbotson, Sindelar, and Ritter 1994).

\section{Information Cascades}

Another explanation of underpricing has to do with investors merely not focusing on the intrinsic value of a stock, but also whether other investors are interested in purchasing (Welch 1992). When investors see no one else purchasing an offering, they may decide not to buy the offering themselves, even if they recognize a potential underpricing. To prevent this scenario, investment bankers may underprice a new listing to ensure that new investors will be interested in purchasing, which will then provoke other investors in a chain-reaction. 


\section{Reducing Legal Liability}

The Securities Act of 1933 makes all participants in the offer who sign the prospectus liable for any material omissions. One way that investment bankers may try to reduce this risk of a lawsuit is by underpricing IPOs. However, this theory is open to debate. A study by Philip Drake and Michael Vetsuypens in 1993 examined 93 IPOs that were sued for misstatements in their IPO prospectus from 1969-1990. The results were that the average initial returns of these companies were similar to a control set of firms that did not get sued. However, they note a significant limitation of their study is that they are unable to observe companies that would have gotten sued had they not underpriced in their IPO. However, Janet Alexander (1993) conducted a study of computer companies in 1983. She discovered that every firm with a $\$ 20$ million loss in market value got sued for approximately $25 \%$ of the decline in market value. This implies that underpricing may make a difference in the likelihood of a lawsuit and could, therefore, be a consideration for investment bankers when pricing an IPO.

\section{Enhancing Banker Relations with Investors}

To satisfy the buy-side end of the transaction, Ibbotson, Sindelar, and Ritter (1994) argue that investment bankers will underprice IPOs to entice investors into doing business with them in the future, perhaps at a higher price. Similarly, they argue that investment bankers take advantage of their market knowledge to intentionally underprice offerings, which boosts their reputation and marketing of their own firm, at the issuing firms' expense. A contradiction to this argument is found in a 1989 study by Chris Muscarella and Michael Vetsuypens that finds when investment banks themselves go public; they tend to underprice their own offerings. 


\section{Long-Term Overpricing Phenomenon}

\section{Overview}

While IPOs outperform the market and are underpriced in the short-term, the contrary is true in the long-term. Jay Ritter's 1991 study finds that from 1975-1984 the return of 1,526 IPOs from the first day of trading to three years later was $34.5 \%$, compared to $61.9 \%$ of the New York Stock Exchange (NYSE). Furthermore, Ibbotson (1975) finds that IPOs offer excess returns in years one and five but computes a negative return in years two through four. One caveat Ibbotson notes is that his sample (120 companies) was not large enough, and therefore there is a high standard of error. There is not a simple explanation for this anomaly - however, Ibbotson, Sandelar, and Ritter's 1994 article detail two possible answers.

\section{Excessive 0ptimism}

An explanation for the long-term underperformance involves the ambiguity of determining an accurate market price for a new offering in its early stages. Because of this, optimistic investors may attribute a higher valuation to a company based on growth opportunities, even though they may never come to fruition. As time passes, more information about the future of an IPOs' growth opportunities becomes more available, and this may reduce the difference in valuations among optimistic and pessimistic investors, lowering the market price.

\section{Impresarios}

Robert Shiller (1990) compares the underpricing of IPOs by investment bankers to create the appearance of excess demand to the promoter of a rock concert trying to make an "event" out of the offering. To this end, Schiller argues that IPOs are subject to fads and 
hype built in the marketplace. This also could relate to the "information cascades" underpricing explanation, where investors choose to buy simply because other people are buying. As a result, this leads to a lower return when investors decide to sell because they see other investors realizing their gains in the aftermarket.

\section{Conclusion}

Overall, Ritter's (1991) empirical evidence shows that if an investor were to hold an IPO from the end of the first day of trading for three years, the investor would have yielded a return of only 83 cents for every dollar invested. There are different interpretations as to why IPOs are underpriced in the short-term but overpriced in the long-term. However,

Ritter (1991) claims that perhaps IPOs are not underpriced in the short-term, but instead, the aftermarket is overpriced. Aftermarket overpricing may be caused by the "Hot Issue" phenomenon and issuing firms choosing to IPO during specific windows of opportunity in the market. 


\section{Hot Issue Markets}

"Hot Issue" markets phenomenon was first put into academic research by Roger Ibbotson and Jeffrey Jaffe in 1975. "Hot Issue" markets are described as a market having an abnormally high return for a specific period. This is a problematic anomaly to rationalize, and even more difficult to predict. Ibbotson, Sandelar, and Ritter (1994) explore three possible explanations for this phenomenon: changes in firm risk, positive feedback or "momentum" strategies, and windows of opportunity.

\section{Changes in Firm Risk}

One hypothesis is that riskier IPOs are underpriced to a greater extent than those that are less risky (Ritter 1980). This is likely a result of the ambiguity involved in pricing a high-risk company with little to no operating history. In this scenario, Ritter (1980) notes that there might be periods in which firms with more risk go public, therefore resulting in higher returns for those periods.

\section{Positive Feedback or "Momentum" Strategies"}

Another theory to explain a hot issue market is that investors follow "positive feedback" strategies (Ibbotson, Sandelar, and Ritter 1994). In this scenario, investors operate under the assumption that IPOs typically lead to high initial returns based on past experiences. If enough investors believe this is the case, it leads to a self-fulfilling prophecy of them all bidding up an IPO and riding the momentum that is caused by this only in during specific periods when this strategy is effective.

\section{Windows of Opportunity}

Hot issue markets may also exist due to issuing firms taking advantage of specific periods in time where investors are more willing to purchase an IPO at high valuation 
multiples. This results in a high volume of new issues and a willingness for issuers to sell the offering at below the aftermarket price (Ibbotson, Sandelar, and Ritter 1994). These opportunities arise only during periods where the stock market is already performing well, and investor sentiment is high, which may lead them to make irrational investing decisions based on optimism during a "hot issue" market period. 


\section{Conclusion}

The research done thus far draws two main conclusions: IPOs are typically underpriced in the short-term, but overpriced in the long-term. A variety of hypotheses attempt to address this phenomenon, which includes the investment banker using IPOs as a way to impress investors, issuing firms opting to IPO during "hot issue" markets, and investors merely being overly-optimistic about companies with little to no operating history. In the next section, I propose an explanation to this anomaly using the Popularity concept, with IPOs holding specific desirable characteristics to investors resulting in a Popularity premium. 


\section{EXAMINING POPULARITY IN THE IPO MARKET}

\section{Overview}

First, the progression from the CAPM formula to the Popularity concept was examined. Popularity offers a set of investor preferences based on characteristics and anomalies of securities. Second, empirical performance in the IPO market and existing possible explanations for the irregularities of short-term underpricing and long-term overpricing was reviewed. In doing so, parallels between the Popularity concept and the performance of the IPO market are evident.

Further exploration of this observation will attempt to determine whether the application of Popularity is valid in the IPO market. Limitations and methods of examination are defined for the proceeding case studies. Twelve companies are identified, then the Popularity of each is determined, followed by evaluating the short-term and longterm returns compared to the S\&P 500 market index. 


\section{Limitations}

Limitations in this study make it difficult to compare to IIKX's (2018) definition of Popularity. IIKX's research divided the investable universe of stocks into four quartiles based on each Popularity attribute, then ranked them from least-preferable to mostpreferable. However, this does not work in the IPO market for specific characteristics, so Popularity is derived from a different measure. Some anomalies/components unmeasurable in the IPO market are brand value, competitive advantage, and company reputation.

- Brand Value - Brand value is impossible to determine in the IPO market relative to IIKX's definition because companies that IPO are typically young would not appear in the Interbrand Annual Top 100 lists. Using brand value as characteristic would require the division of brand value into four quartiles for companies that IPO during a specified period, which this study does not include.

- Competitive Advantage - Similarly, Morningstar's economic moat ratings cannot be used sufficiently in the IPO market because Morningstar does not provide a moat rating for smaller and private companies that are pre-IPO.

- Reputation - Nielson's Harris Poll reputation quotient also cannot be used due to the reasons listed above. A reputation quotient for companies before going public would need to be studied.

Other limitations of this study include the inability to accurately attain IPO data relative to quartile values for beta and volatility and severe downside risk. Beta assumptions can only be estimated, and without prior public market history, an IPO's beta before going to the public would be impossible to calculate. 


\section{Methodology}

Testing whether the Popularity concept applies to the IPO market would help predict future returns for an issuing firm going public. First, four different IPO's from three different periods were selected. They are classified as such: the "Internet Boom" period taking place from 1997-2000, the "Post-Internet Boom" taking place from 2002-2005, and the "App" period from 2012-present. It includes the companies listed below: (Note: these companies are not randomly selected, but instead are a combination of well-known companies and a random mix of less-known companies).

- Internet Boom: Amazon.com Inc. (1997), eBay Inc. (1998), United Parcel Service (1999), Stamps.com (1999)

- Post-Internet Boom: Netflix Inc. (2002), Axis Capital Holdings (2003), Google Inc. (2004), Domino's Pizza Inc. (2004).

- App Period: Facebook Inc. (2012), Twitter Inc. (2013), Shake Shack Inc. (2015), Snap Inc. (2017)

Due to the limitations mentioned above, a different measure of Popularity was determined. First, fundamental analysis of the company before IPO identifies general investor sentiment for each issuing firm. This research involves examining the issuing firm's Form 424B1 Prospectus, along with relevant news articles at the time. Instead of evaluating each issuing firms' Popularity characteristics, a company's first-day "pop" is the proxy to gauge the Popularity of each security at the time of IPO. Specifically, companies below the $16.4 \%$ average first-day return (Ritter 1991) are Unpopular, while companies above $16.4 \%$ are to be Popular (with a 100BPS discretion). The issuing period during each 
firms' IPO is also accounted for to determine implied investor sentiment that may have influenced a first-day "pop." After evaluating the issuing firms' fundamental traits, first-day returns, and the issuing period, event time formulated returns for one-month, one-year, three-years, and five years post-IPO get calculated. The first-day volume versus proceeding one-month trading volume is also used to determine Popularity. This data is from Yahoo Finance's Historical Data Database. I hypothesize that the larger a company's "pop" is on the first day, the more overpriced the stock will be in the long-term, resulting in a lower return compared to the market. 


\section{CASE STUDIES}

\section{\#1 - Amazon.com (AMZN)}

\section{Company Background}

Founded in 1994, Amazon.com was originally an online marketplace for books. When it filed for IPO in 1997, there was no clear path to profitability. Still, they claimed themselves to be “Earth’s Biggest Bookstore” (Amazon Com 1997). In their 1997 prospectus, they boast about having virtually unlimited shelf space, offering more than 2.5 million titles. Amazon.com also grew to fame when Time magazine rated one of the 10 "Best Websites of 1996." Also, in the prospectus, they highlight the $100 \%$ sales growth from Q1 1996 through Q1 1997. However, they mention that the company is growing at the expense of sacrificing profits. They had incurred \$8.8 million in losses in years 1996 and 1997, which Amazon.com cites as one of their risk factors.

\section{Issuing Period}

Amazon.com went public on the cusp of one of the hottest issuing periods

historically, the dot com boom. Before the bubble burst, investors were excited about any company with "dot com" in the name. To understand investor sentiment toward IPOs in this period, the average first-day returns on IPOs in 1996 was $17 \%$ but had skyrocketed to 73\% by 1999 (Ljungqvist, Wilhelm Jr. 2003). This shift in average first-day returns shows how investors were not behaving rationally during this time, which led to vast initial underpricing in the IPO market. 


\section{Findings}

The first day of trading AMZN had volume of 72.16 million compared to a 30-day average volume of 9.238 million. As seen in figure 1.1, AMZN had a 29.97\% spike on its first day of trading (adjusted for return of the S\&P 500). Amazon.com's first-day pop, in addition to the information above, means Amazon.com was a highly anticipated IPO and should be considered Popular. Due to the short-term underpricing and consideration of Amazon.com as a Popular stock at IPO should lead to a lower long-term adjusted return in comparison to the broader market. However, this is not the case. While the one-month adjusted return was negative (-25.25\%), Amazon significantly outperformed the market one year, three years, and five years post-IPO.

Figure 1.1 - Amazon.com's Raw and Adjusted Returns May 15, 1997 - May 15, 2002

\begin{tabular}{|c|c|c|c|}
\hline \multirow{2}{*}{ Timeframe } & \multicolumn{3}{|c|}{ Return } \\
\cline { 2 - 4 } Date of IPO & Raw & S\&P 500 & Adjusted \\
$\mathbf{0 5 / 1 5 / 1 9 9 7}$ & $30.67 \%$ & $0.70 \%$ & $29.97 \%$ \\
\hline One Month & & & \\
\hline $\mathbf{0 5 / 1 5 / 1 9 9 7 - 0 6 / 1 5 / 1 9 9 7}$ & $-19.15 \%$ & $6.10 \%$ & $-25.25 \%$ \\
\hline One Year & $294.90 \%$ & $32.72 \%$ & $262.18 \%$ \\
05/15/1997- 05/15/1998 & & & $2,573.57 \%$ \\
\hline Three Years & $2,642.35 \%$ & $68.78 \%$ & \\
\hline 05/15/1997- 05/15/2000 & & & $733.95 \%$ \\
\hline Five Years & $764.29 \%$ & $30.34 \%$ & \\
\hline
\end{tabular}

While this is inconsistent with both the Popularity concept and Ritter's empirical evidence regarding the long-term overpricing of IPO's, Amazon may be considered an 
anomaly for the adaptation of its business model. In its prospectus, investors may have been under the assumption that Amazon would only experience growth through the sale of books. However, they quickly adapted their site to sell a variety of different products and opened their doors to third-party sellers in 2000 . This changed the growth trajectory of the company and is what helped turn it into the behemoth company that it is today. 


\section{\#2 - eBay Inc. (EBAY)}

\section{Company Background}

On September 24, 1998, eBay Inc. filed for IPO. At the time, the company was "the world's largest and most popular person-to-person trading community on the Internet" (eBay Inc. 1998). eBay was one of the first companies to create an online marketplace for both buyers and sellers, using an auction format for users to sell a variety of goods on the site. Before IPO, eBay was just three years old but had already conducted over 15 million auctions with gross merchandise sales of $\$ 340$ million. The company was able to leverage the technology provided through the Internet to reduce inefficiencies in marketplace transactions. With only three years of operating experience, the company highlighted its short lifespan as a potential risk factor in the prospectus. That said, in comparison to Amazon.com, eBay was cash-flow positive pre-IPO, which made investors particularly interested in the company.

\section{Issuing Period}

Despite issuing about 18 months after Amazon.com, the market was still craving IPO's, particularly Internet firms. This made eBay an attractive offering, especially given their existing profits, which was unique for a high-growth Internet company. A unique aspect of both eBay and Amazon.com is that they went public right before the height of the dot com boom, which occurred between 1999-2000. According to Ljungqvist and Wilhelm Jr. (2003), high-tech companies accounted for about one-third of IPO's between 1996-1998 but had risen to one-half in 1999-2000. The Popularity of tech IPO's in the market was growing over the same period that eBay went public. 


\section{Findings}

On its first day of trading, eBay Inc. shares had a volume north of 518 million, compared with its first-month average of 72.50 million. While investors typically trade a stock more on the date of its IPO, this is still representative of the amount of anticipation leading up to eBay's IPO. On the first day of trading, shares spiked $162.94 \%$ from $\$ 18$ to $\$ 47.33$ per share. eBay was already a profit-generating and high-growth company at the time of IPO, and their first-day pop makes eBay Inc. Popular. Therefore, the consistent Popularity theory suggests that eBay is overpriced in its offering and should underperform the market in the long-term. As seen in figure 2.1, this is not the case, as eBay cumulatively outperformed the S\&P 500 by 1,304.92\% over the five years post-IPO. eBay was close to a return similar to the S\&P 500 one-month after trading.

Figure 2.1 - eBay Inc's Raw and Adjusted Returns September 24, 1998 - September 24,2003

\begin{tabular}{|c|c|c|c|}
\hline \multirow{2}{*}{ Timeframe } & \multicolumn{3}{|c|}{ Return } \\
\hline & Raw & S\&P 500 & Adjusted \\
\hline $\begin{array}{c}\text { Date of IPO } \\
09 / 24 / 1998\end{array}$ & $162.94 \%$ & $-2.19 \%$ & $165.13 \%$ \\
\hline $\begin{array}{c}\text { One Month } \\
09 / 24 / 1998-10 / 24 / 1998\end{array}$ & $6.02 \%$ & $2.68 \%$ & $3.34 \%$ \\
\hline $\begin{array}{c}\text { One Year } \\
09 / 24 / 1998-09 / 24 / 1999\end{array}$ & $825.30 \%$ & $22.50 \%$ & $802.80 \%$ \\
\hline $\begin{array}{c}\text { Three Years } \\
09 / 24 / 1998-09 / 24 / 2001\end{array}$ & $455.42 \%$ & $-3.77 \%$ & $459.19 \%$ \\
\hline $\begin{array}{c}\text { Five Years } \\
09 / 24 / 1998-09 / 24 / 2003\end{array}$ & $1,303.61 \%$ & $-1.31 \%$ & $1,304.92 \%$ \\
\hline
\end{tabular}


eBay's outperformance has to do more with the anomalistic nature of the issuing firm than typical tendencies in the IPO market. While many companies failed to survive the dot com bubble, eBay was one of few companies that persevered through the crash. This may have to do with the fact that eBay was already the largest auction site during the boom and was, therefore, able to achieve a critical mass of users before the market plunged and investor sentiment turned away from tech-IPOs. In the cases of Amazon and eBay, both filed for IPO just before the red-hot issuing period of 1999-2000. A compelling study in the future may be to evaluate the returns of IPOs filed just before a hot issue period to determine if investors can achieve superior long-term performance during these periods. 


\section{\#3 - United Parcel Service (UPS)}

\section{Company Background}

The United Parcel Service (UPS), founded in 1907, went public nearly a century later in 1999. By this time, the company had grown into the world's largest package delivery company (United Parcel 1999). In 1998 the company had over 330,000 employees and delivered over three billion packages, resulting in revenue of $\$ 24.8$ billion and a net income of $\$ 1.7$ billion. Being one of the first privatized delivery companies, UPS had an economic moat in an industry that is exceptionally capitally intensive. In their prospectus, they cite that their main strategies for growth will come from expanding their domestic business, along with leveraging their technology to create an advantage for customers to choose them for e-commerce.

\section{Issuing Period}

UPS issued near the height of the dot com bubble in 1999 when the market was overly excited about IPOs. The average return on IPOs in 1999 was 73\% (Ljungqvist, Wilhelm Jr. 2003), which makes UPS' 36\% first-day return look modest. While UPS itself was not an e-commerce company, its role as a package delivery service may have influenced investor excitement as they believed UPS could capitalize on this growing industry.

\section{Findings}

On the first day of trading, UPS stock soared to close $36 \%$ above its IPO price. Volume for the day was 80.8 million, nearly ten times higher than the proceeding onemonth average of 8.6 million. At the time, UPS would be considered a Popular IPO, due to 
its first-day pop and the growth potential of the company. What may have enticed investors additionally was that the company was already profitable and was well-established. While the existing maturity of a company can sometimes lower investor expectations about growth, the correlation of their delivery service to the Internet likely refuted this distaste.

Figure 3.1 - United Parcel Services' Raw and Adjusted Returns November 11, 1999 November 11, 2004

\begin{tabular}{|c|c|c|c|}
\hline \multirow[t]{2}{*}{ Timeframe } & \multicolumn{3}{|c|}{ Return } \\
\hline & Raw & S\&P 500 & Adjusted \\
\hline $\begin{array}{c}\text { Date of IPO } \\
11 / 10 / 1999\end{array}$ & $36 \%$ & $0.60 \%$ & $35.40 \%$ \\
\hline $\begin{array}{c}\text { One Month } \\
11 / 10 / 1999-12 / 10 / 1999\end{array}$ & $-3.11 \%$ & $2.52 \%$ & $-5.63 \%$ \\
\hline $\begin{array}{c}\text { One Year } \\
11 / 10 / 1999-11 / 10 / 2000\end{array}$ & $-14.10 \%$ & $1.94 \%$ & $-16.04 \%$ \\
\hline $\begin{array}{c}\text { Three Years } \\
11 / 10 / 1999-11 / 10 / 2002\end{array}$ & $-8.66 \%$ & $-34.86 \%$ & $26.2 \%$ \\
\hline $\begin{array}{c}\text { Five Years } \\
11 / 10 / 1999-11 / 10 / 2004\end{array}$ & $20.50 \%$ & $-15.24 \%$ & $35.74 \%$ \\
\hline
\end{tabular}

However, contrary to both eBay and Amazon, UPS offered a negative one-year return even while the S\&P 500 produced a positive return, which may hint at an overpricing on its IPO date due to its popularity (see figure 3.1). On the contrary, UPS outperformed the broader market by $26.2 \%$ and $35.74 \%$ three years and five years postIPO, respectively. While this is inconsistent with Popularity, this may be because of the overall market downturn, rather than UPS' outperformance. Additionally, investors may 
have still considered it a favorable investment due to its growth potential and consistent profitability relative to other companies in the market. 


\section{\#4 - Stamps.com (STMP)}

\section{Company Background}

At the time of IPO in 1999, Stamps.com had no revenue; the first such case reviewed in this paper. However, its business plan was to operate a variety of product and service lines, selling mainly USPS stamps and postage at a discounted rate and charging a monthly service fee. The stamps and postage were to be printable from the users' accounts online. In their prospectus, they note the most significant risk factor is that their product was not yet approved by USPS, which is crucial to their business model. That said, Stamps.com they believe that USPS will approve their software-based service (Stamps.com 1999). From January 9, 1998 - March 31, 1998, Stamps.com suffered an operating loss of \$363 million. Their growth strategy was to be the leading provider in convenient, cost-effective, and easy use Internet software to provide postage services.

\section{Issuing Period}

Filing for IPO on June 25, 1999, Stamps.com issued during what many consider to be the height of the dot com bubble. The market was in favor of Internet companies at the time, and Stamps.com fit perfectly into this criterion. Additionally, they would be able to capitalize on the increased growth in the Internet and e-commerce space, which led to excitement for investors.

\section{Findings}

On the day of its public offering, Stamps.com had over three million in trading volume, more than three times their proceeding one-month average of 996 thousand. As a result, the stock price increased by $148.91 \%$ (see figure 4.1 ). This, in addition to the growth 
opportunities mentioned above, leads to the belief that Stamps.com was a Popular IPO issuing in a period of irrational investor behavior. Stamps.com should experience underpricing in the short-term that will ultimately lead to overpricing in the long-term.

Figure 4.1 - Stamps.com's Raw and Adjusted Returns June 25, 1999 - June 25, 2004

\begin{tabular}{|c|c|c|c|}
\hline \multirow{2}{*}{ Timeframe } & \multicolumn{3}{|c|}{ Return } \\
\cline { 2 - 4 } & Raw & S\&P 500 & Adjusted \\
\hline Date of IPO & $148.91 \%$ & $-0.04 \%$ & $148.95 \%$ \\
$\mathbf{0 6 / 2 5 / 1 9 9 9}$ & & & \\
\hline One Month & $222.32 \%$ & $3.13 \%$ & $219.19 \%$ \\
06/25/1999- 07/25/1999 & & & $-43.78 \%$ \\
\hline One Year & $-34.23 \%$ & $9.55 \%$ & $-42.78 \%$ \\
\hline 06/25/1999- 06/25/2000 & & & \\
\hline Three Years & $-68.59 \%$ & $-25.81 \%$ & $-48.82 \%$ \\
\hline 06/25/1999- 06/25/2002 & & & \\
\hline Five Years & $-62.13 \%$ & $-13.31 \%$ & \\
\hline
\end{tabular}

As seen in figure 4.1, this was the case. Stamps.com substantially outperformed the S\&P 500 in both first day and one-month returns, up nearly 220 percent by July 25, 1999 . However, even as the market performed well throughout the following year, Stamps.com's stock price fell 34.23 percent. This trend continued throughout their three-year and fiveyear adjusted returns, as the stock closed -62.13 percent down from its first day of trading on June 25, 2004. This is the first case that is consistent with both Ritter's IPO long-term overpricing theory in addition to the Popularity concept. This may be due to the timing of the IPO, along with Stamps.com's business model. Stamps.com utilized this hot issuing period to raise capital despite having no prior revenues. Once investors began behaving 
rationally, they found that they underestimated the risks associated with investing in a company in its pre-revenue stages. This led to a contraction in investments, ultimately lowering the stock price in the long-term. 


\section{\#5 - Netflix Inc. (NFLX)}

\section{Company Background}

Netflix began in 1997, but by the time of its IPO was the largest online entertainment subscription service in the United States with more than 600,000 customers. At the time, Netflix's core business model was physically shipping DVD's and VCR's to consumers in exchange for a monthly fee. In their 2002 prospectus, they cite that their growth is driven by their large selection, high customer satisfaction, and rapid adoption of DVD players (Netflix Inc., 2002). Their primary belief was that without owning physical stores, they could cut costs and create a scalable product to expand their subscriber base quickly. In the year ended December 31,2001 , Netflix had more than $\$ 75$ million in sales but operated at a net loss of $\$ 38.6$ million.

\section{Issuing Period}

In 2002, investors had just come out of the shaky dot com bubble, which was fresh in their minds. A 2002 article written by Steve Gelsi for MarketWatch notes that “Technology deals are few and far between in the IPO market nowadays -." He adds that big IPO deals for investors are "still parse" (Gelsi 2002). This article sheds light on the behavioral thinking of investors at the time. The issuing period was far from hot, and it was difficult to find technology companies filing for IPO at all. This was a far stretch from where the market had been just a few years earlier.

\section{Findings}

On May 23, 2002, Netflix went public and had a volume of 105 million, compared to an average size of 9.5 million for the following month. While the volume had spiked, 
Netflix's share price only jumped $12.00 \%$ on the day of IPO (see figure 5.1), a modest return compared to those seen during the dot com bubble. That said, it came less than a year after a recession in which the market pulled back on sentiment for technology IPOs. Given implied investor sentiment, along with Netflix earning a lower than the historical average (16.4\%) on its first-day pop, Netflix was Unpopular. As a result, the stock price is undervalued in the short-term and will lead to a higher long-term return.

Figure 5.1 - Netflix Inc's Raw and Adjusted Returns May 23, 2002 - May 23, 2007

\begin{tabular}{|c|c|c|c|}
\hline \multirow[t]{2}{*}{ Timeframe } & \multicolumn{3}{|c|}{ Return } \\
\hline & Raw & S\&P 500 & Adjusted \\
\hline $\begin{array}{c}\text { Date of IPO } \\
05 / 23 / 2002\end{array}$ & $12.00 \%$ & $1.02 \%$ & $10.98 \%$ \\
\hline $\begin{array}{c}\text { One Month } \\
05 / 23 / 2002-06 / 23 / 2002\end{array}$ & $-18.33 \%$ & $-8.92 \%$ & $-9.41 \%$ \\
\hline $\begin{array}{c}\text { One Year } \\
05 / 23 / 2002-05 / 23 / 2003\end{array}$ & $31.67 \%$ & $-14.07 \%$ & $45.74 \%$ \\
\hline $\begin{array}{c}\text { Three Years } \\
05 / 23 / 2002-05 / 23 / 2005\end{array}$ & $85.00 \%$ & $9.93 \%$ & $75.07 \%$ \\
\hline $\begin{array}{c}\text { Five Years } \\
05 / 23 / 2002-05 / 23 / 2007\end{array}$ & $174.17 \%$ & $40.34 \%$ & $133.83 \%$ \\
\hline
\end{tabular}

In the case of Netflix, this was what happened. After suffering a one-month adjusted return of $-9.41 \%$, Netflix's stock price bounced back in years one, three, and five to significantly outperform the broader market by $45.74 \%, 75.07 \%$, and $133.83 \%$, respectively. While this fits the Popularity concept, other stock-specific characteristics may have also influenced this result. Specifically, in their prospectus, Netflix makes no note 
about the potential move to an online streaming service. Once this occurred, scaling was much more achievable, and operating costs reduced drastically. 


\section{\#6 - Axis Capital Holdings LTD (AXS)}

\section{Company Background}

Founded in 2001, Axis Capital provides specialty lines insurance and treaty reinsurance, headquartered in Bermuda. In their 2003 prospectus, Axis Capital notes that they had $\$ 1.1$ billion in gross premiums and generated net income of $\$ 107.1$ million. Specialty lines insurance relates to risks involved in items such as terrorism, marine and aviation war threat, and political uncertainties, among others. Axis Capital also highlight their strategies, which include managing a diverse portfolio of specialty risks and highly disciplined underwriting practices.

\section{Issuing Period}

As mentioned in the above Netflix case, the market was still recovering from the irrationality during the dot com boom. That said, Axis Capital's July 2003 IPO was a little more than a year removed from Netflix. In this time, David Westenberg of WilmerHale notes in an article that while there were only seven IPOs in the United States in the first half of 2003, there were 64 in the following six months. Of the IPOs in 2003, 21 percent were offerings by financial services and insurance companies (Westenberg 2004). Additionally, 56 of the 71 IPOs in 2003 traded at or above their offering price by year-end. Overall, the market sentiment toward IPOs appeared to be trending upward in the latter half of the year.

\section{Findings}

Axis Capital traded with a volume of 11.6 million during its first day of trading (July 01, 2003), higher than its proceeding one-month average volume of one million. 
Additionally, the price jumped $16.14 \%$ during its first day of trading, much higher than the broader market return of only $0.80 \%$. My initial thesis was that Axis Capital was Unpopular. However, given its first-day pop that is only 26 BPS from the average and growing implied investor sentiment in the IPO market in the second half of 2003, it appears that Axis was, in fact, Popular. Therefore, Axis should be underpriced in the short-term but overvalued in the long-term.

Figure 6.1 - Axis Capital Holdings' Raw and Adjusted Returns July 01, 2003 - July 01, 2008

\begin{tabular}{|c|c|c|c|}
\hline \multirow{2}{*}{ Timeframe } & \multicolumn{3}{|c|}{ Return } \\
\cline { 2 - 4 } & Raw & S\&P 500 & Adjusted \\
\hline $\begin{array}{c}\text { Date of IP0 } \\
\text { 07/01/2003 }\end{array}$ & $16.14 \%$ & $0.80 \%$ & $15.34 \%$ \\
\hline One Month & $-0.20 \%$ & $0.58 \%$ & $-0.78 \%$ \\
$\mathbf{0 7 / 0 1 / 2 0 0 3 - 0 8 / 0 1 / 2 0 0 3}$ & & & $-6.50 \%$ \\
\hline One Year & $9.35 \%$ & $15.85 \%$ & $-16.25 \%$ \\
\hline $\mathbf{0 7 / 0 1 / 2 0 0 3 - 0 7 / 0 1 / 2 0 0 4}$ & & & \\
\hline Three Years & $14.09 \%$ & $30.34 \%$ & $-14.21 \%$ \\
\hline 07/01/2003- 07/01/2006 & & & \\
\hline Five Years & $17.14 \%$ & $31.35 \%$ & \\
\hline
\end{tabular}

As seen in figure 6.1, this appears to be the case. Axis Capital's share price underperformed the broader market in each period examined after its IPO, which is consistent with the Popularity concept. An explanation may be that nothing significantly changed from their strategies in the prospectus throughout their first five years operating 
as a public entity, resulting in decreased investor interest in the company after its first day

of trading. 


\section{\#7 - Google Inc. - now Alphabet Inc. (GOOGL)}

\section{Company Background}

Google was founded in 1998 and by 2004 was a global leader in web search and advertising. Their revenue model is selling targeted advertisements to advertisers. In 1999 Google was not profitable; in the year ended December 31, 2003, Google generated \$105.6 in net income on revenues of $\$ 1.46$ billion (Google Inc. 2004). At the time, Google still faced significant competition from both Microsoft and Yahoo. Additionally, more than $98 \%$ of their revenue came from advertising, which they mention is a risk if reductions in advertising spending took place.

\section{Issuing Period}

By 2004 , the IPO market was four years removed from the dot com bubble, and the IPO market was heating up. A CNN Money article in September 2004 by Mark Gongloff notes that new offerings had gained an average 10 percent for the year, outperforming the broader market. 2004 also had the most significant number of IPOs since 2000 with 140 offerings. Overall, the IPO market was in a better place than in recent years, albeit still not as hot as the dot com period.

\section{Findings}

Google was one of the most highly anticipated IPOs of all time as they were a profitable high-growth company with a proven business model. As a result, the company had a first-day trading volume of nearly 45 million compared to a proceeding 11 million one-month average, as the stock gained an adjusted 18.41 percent. Given the positive implied investor sentiment toward the company, in addition to its first-day pop, there is no 
denying that Google was a Popular IPO. For this reason, they should be underpriced in the short-term but overpriced in the long-term.

Figure 7.1 - Google (Alphabet Inc's) Raw and Adjusted Returns August 19, 2004 August 19, 2009

\begin{tabular}{|c|c|c|c|}
\hline \multirow{2}{*}{ Timeframe } & \multicolumn{3}{|c|}{ Return } \\
\cline { 2 - 4 } & Raw & S\&P 500 & Adjusted \\
\hline $\begin{array}{c}\text { Date of IPO } \\
\text { 08/19/2004 }\end{array}$ & $18.05 \%$ & $-0.36 \%$ & $18.41 \%$ \\
\hline One Month & & & \\
\hline $\mathbf{0 8 / 1 9 / 2 0 0 4 - 0 9 / 1 9 / 2 0 0 4}$ & & $3.42 \%$ & $13.66 \%$ \\
\hline One Year & $17.08 \%$ & & \\
\hline $\mathbf{0 8 / 1 9 / 2 0 0 4 - 0 8 / 1 9 / 2 0 0 5}$ & & $11.77 \%$ & $167.28 \%$ \\
\hline Three Years & $398.34 \%$ & $32.51 \%$ & $365.83 \%$ \\
\hline $\mathbf{0 8 / 1 9 / 2 0 0 4 - 0 8 / 1 9 / 2 0 0 7}$ & & & $351.78 \%$ \\
\hline Five Years & $342.47 \%$ & $-9.31 \%$ & \\
\hline
\end{tabular}

As shown in figure 7.1, Google outperformed the broader market in every period studied. This is not consistent with the Popularity concept, although this is due to the anomalistic nature of Google's business model. Over the five years post-IPO, Google's competitors struggled to keep up with their explosive gains in market share. Additionally, Google expanded its lines of business, as well as acquiring YouTube in 2006. The sheer growth of the company was something that Google hinted at in their prospectus, and that is likely why the stock never dipped below their IPO price. 


\section{\#8 - Domino's Pizza Inc. (DPZ)}

\section{Company Background}

Domino's Pizza was founded in 1960, although it did not go public until 44 years later. By 2004, Domino's was the number one pizza delivery company in the United States. As per their prospectus, Domino's had $\$ 1.33$ billion in net revenues resulting in $\$ 46$ million net income for the fiscal year 2003 (Domino's Pizza 2004). Domino's most considerable strengths were in their growth model (franchises), and their existing profitability pre-IPO. However, risks to be considered were its competition in a highly competitive industry, and quick changes in consumer preferences could significantly hurt their business.

\section{Issuing Period}

Filing just a month before Google Inc., the issuing period was largely heating up. Investors were recovering from the shocks post-dot com boom and were willing to get back into the market. There was also a recovery in the first-day pop prices, with the average IPO gaining $10 \%$ on the first day of trading for quarter one - quarter three, 2004 (Gangloff 2004).

\section{Findings}

Domino's Pizza had a first-day trading volume of 15 million, much higher than their proceeding one-month average of 1.4 million. That said, the stock price dropped 3.57 percent from its initial price. Citing a Forbes article from after-hours on the first day of trading, Domino's Pizza did not deliver a strong IPO. It appears that other than their strong brand name, the prospectus did not deliver anything else exciting for investors. Given the above evaluation, Domino's was an Unpopular IPO. If consistent with Popularity, this would result in a superior long-term return. 
Figure 8.1 - Domino's Pizza Inc's Raw and Adjusted Returns July 13, 2004 - July 13, 2009

\begin{tabular}{|c|c|c|c|}
\hline \multirow[t]{2}{*}{ Timeframe } & \multicolumn{3}{|c|}{ Return } \\
\hline & Raw & S\&P 500 & Adjusted \\
\hline $\begin{array}{c}\text { Date of IPO } \\
07 / 13 / 2004\end{array}$ & $-3.57 \%$ & $-0.07 \%$ & $-3.50 \%$ \\
\hline $\begin{array}{c}\text { One Month } \\
07 / 13 / 2004-08 / 13 / 2004\end{array}$ & $-0.74 \%$ & $-4.51 \%$ & $3.77 \%$ \\
\hline $\begin{array}{c}\text { One Year } \\
\text { 07/13/2004 - 07/13/2005 }\end{array}$ & $77.04 \%$ & $9.70 \%$ & $67.34 \%$ \\
\hline $\begin{array}{c}\text { Three Years } \\
07 / 13 / 2004-07 / 13 / 2007\end{array}$ & $37.33 \%$ & $36.53 \%$ & $0.80 \%$ \\
\hline $\begin{array}{c}\text { Five Years } \\
07 / 13 / 2004-07 / 13 / 2009\end{array}$ & $-44.51 \%$ & $-21.16 \%$ & $-23.35 \%$ \\
\hline
\end{tabular}

In reference to figure 8.1, Domino's stock experienced volatile adjusted returns from one year, three years, and five years post-IPO. One year post-IPO, the company was strongly outperforming the S\&P 500 benchmark. However, by 2009, DPZ was underperforming by nearly 25 percent. It appears that Domino's returns were inconsistent with the Popularity concept as it underperformed in the long-term while also underperforming in the short-term. That said, if one were to look beyond the scope of five years, Domino's has dramatically outperformed the broader market starting in 2010, with a 1,800 percent return from its IPO price to 15 years later. This may imply that the "longterm" return for a company is not captured within a five-year scope, and further studies require a longer timeframe is needed. 


\section{\#9 - Facebook Inc. (FB)}

\section{Company Background}

Facebook Inc. began in 2004 by founder and CEO Mark Zuckerberg. As per their 2012 prospectus, Facebook is a social networking platform with over 900 million monthly active users (MAUs). Facebook leverages its massive user base to serve as a platform for advertisers based on their desired demographics from a users' profile. At the time, it was unique for Advertisers to be able to target such specific audiences. The company had a net income of $\$ 1$ billion on nearly $\$ 4$ billion in revenue for the year ended 2011. One of the most considerable uncertainties for Facebook was to be able to maintain relevance in an ever-growing competitive market.

\section{Issuing Period}

In 2012, the world was just a few years removed from the financial crisis, and the economy was in recovery. There were many uncertainties regarding the budget of the United States and the European debt crisis. According to Karina Frayter of CNBC in 2011, analysts were skeptical of web-based IPOs without proven business models and believed that their offerings might disappoint investors. Overall, the market seemed weary from the losses suffered during the great recession, and investors were not eager to jump on unproven companies.

\section{Findings}

Facebook traded with a first-day volume of over 500 million compared with an average of 81 million for the month. Despite this, the company only gained a mere 0.61 percent on its first day. It appears the 2011 predictions were right, and investors were not 
ready to enter the technology IPO space. Suffice to say that despite Facebook being an anticipated IPO, it was Unpopular, and the market was unprepared. According to the Popularity concept, this should result in a lower short-term return, followed by a higher long-term performance.

Figure 9.1 - Facebook Inc's Raw and Adjusted Returns May 18, 2012 - May 18, 2012

\begin{tabular}{|c|c|c|c|}
\hline \multirow[t]{2}{*}{ Timeframe } & \multicolumn{3}{|c|}{ Return } \\
\hline & Raw & S\&P 500 & Adjusted \\
\hline $\begin{array}{l}\text { Date of IPO } \\
05 / 18 / 2012\end{array}$ & $0.61 \%$ & $-0.76 \%$ & $1.37 \%$ \\
\hline $\begin{array}{c}\text { One Month } \\
05 / 18 / 2012-06 / 18 / 2012\end{array}$ & $-21.71 \%$ & $3.83 \%$ & $-25.54 \%$ \\
\hline $\begin{array}{c}\text { One Year } \\
05 / 18 / 2012-05 / 18 / 2013\end{array}$ & $-31.34 \%$ & $28.74 \%$ & $-60.08 \%$ \\
\hline $\begin{array}{c}\text { Three Years } \\
05 / 18 / 2012-05 / 18 / 2015\end{array}$ & $111.56 \%$ & $64.39 \%$ & $47.17 \%$ \\
\hline $\begin{array}{c}\text { Five Years } \\
05 / 18 / 2012-05 / 18 / 2017\end{array}$ & $278.89 \%$ & $81.98 \%$ & $196.91 \%$ \\
\hline
\end{tabular}

As seen in figure 9.1, the company's share price had retreated an adjusted 60.08 percent one year after going public. However, in the following three- and five-year periods, Facebook outperformed the market by 47.17 and 196.91 percent, respectively. Facebook's case is consistent with the Popularity concept. When looking for possible explanations outside of Popularity, investors may not have understood the high-profit nature of their business model. Additionally, with the broader market also performing well, investors may have built a more extensive risk tolerance than at the time of IPO, which drew more investment into Facebook. 


\section{\#10 - Twitter Inc. (TWTR)}

\section{Company Background}

Twitter Inc. began in 2006, filing for IPO seven years later in 2013. Like Facebook, Twitter is a social networking company. By 2013, the company had accumulated more than 215 million monthly active users (MAUs). One way that Twitter portrays itself as different from Facebook is that they have platform partners such as media outlets that display media content. These partners do not directly generate revenue for Twitter but instead allow generated network effects to enhance the user experience which increases advertiser spend positively. At the time of IPO, Twitter was multiplying, with a 198 percent increase in revenue from 2011 to 2012 (Twitter Inc. 2004). However, Twitter was operating at a net loss of nearly \$80 million in the year ended December 31, 2012.

\section{Issuing Period}

A lot changed in the IPO market from 2012 to 2013. Two hundred twenty-two companies went public, which was the most since 2000. Technology IPOs made up 45 of the 222, with the average first-day "pop" returns at 17\% (Keating 2014). Additionally, the general market was transitioning into from recovery into expansion and implied investor sentiment was high. 2014 was a hot issue period in the IPO market.

\section{Findings}

Twitter had a first-day trading volume of 117 million compared to 14.8 million for the proceeding month. The stock price also jumped 72.69 percent, making it one of the best IPO first-day returns in 2013. Twitter presented an opportunity for investors who may have felt that they missed out on Facebook's IPO, this time in a more robust market. Given 
their first day spike in trading, Twitter is undoubtedly considered Popular. This means the company should be overvalued in the long-term.

Figure 10.1 - Twitter Inc's Raw and Adjusted Returns November 07, 2013 November 07, 2018

\begin{tabular}{|c|c|c|c|}
\hline \multirow[t]{2}{*}{ Timeframe } & \multicolumn{3}{|c|}{ Return } \\
\hline & Raw & S\&P 500 & Adjusted \\
\hline $\begin{array}{l}\text { Date of IPO } \\
11 / 07 / 2013\end{array}$ & $72.69 \%$ & $-1.33 \%$ & $74.02 \%$ \\
\hline $\begin{array}{c}\text { One Month } \\
11 / 07 / 2013-12 / 07 / 2013\end{array}$ & $0.11 \%$ & $3.32 \%$ & $-3.21 \%$ \\
\hline $\begin{array}{c}\text { One Year } \\
11 / 07 / 2013-11 / 07 / 2014\end{array}$ & $-10.22 \%$ & $16.30 \%$ & $-26.52 \%$ \\
\hline $\begin{array}{c}\text { Three Years } \\
11 / 07 / 2013-11 / 07 / 2016\end{array}$ & $-60.00 \%$ & $22.00 \%$ & $-82 \%$ \\
\hline $\begin{array}{c}\text { Five Years } \\
11 / 07 / 2013-11 / 07 / 2018\end{array}$ & $-23.34 \%$ & $57.71 \%$ & $-81.05 \%$ \\
\hline
\end{tabular}

Twitter's IPO case is consistent with Popularity. As seen in figure 10.1, Twitter only outperformed the broader market on its first-day pop and has dropped in each period since. While investors may have been excited about the company at the time of IPO, there is growing concern about the profitability of Twitter. On the contrary, Facebook performed exceedingly well during this time, already having a larger user base and a net income. Perhaps investors lost interest in Twitter and shifted attention to Facebook, resulting in a large difference in returns. 


\section{\#11 - Shake Shack Inc. (SHAK)}

\section{Company Background}

Shake Shack was founded in 2004 and went public 11 years later in 2015. Shake Shack brands itself as a modern burger chain, serving classic American food such as burgers, hot dogs, and shakes. The company's business model includes a combination of both company-owned and franchised locations. At the time of the prospectus Shake Shack had a total of 63 stores, 31 being company-owned, five domestically licensed, and 27 internationally licensed (Shake Shack 2014). Their focus is on building stores in densely populated areas such as New York City. Shake Shack mentions that it is in its early stages of growth, with plans for 450 company-owned stores and growing their presence internationally. In doing so, they also hope to improve same-store sales growth significantly as Shake Shack increases its brand awareness. For the fiscal year ended December 25, 2013, Shake Shack had revenue of $\$ 82.4$ million, resulting in net income of $\$ 5.4$ million. Most of this revenue came from sales at their company-owned locations, with licensing revenue accounting for only 5 percent of sales.

\section{Issuing Period}

The issuing period of 2015 had 170 total IPOs, which was substantially lower from 2014, where 244 companies went public (Renaissance Capital 2016). The 2015 IPO market was a disappointment to investors who were looking for a continuation of the past two years of hot issue periods. The average return for IPOs during this period was down two percent for the year. When looking for explanations, uncertainties remained in both the Federal Reserve and European monetary policies, which likely drove down IPO returns. Still, there were winners in this period. Overall, while the market was not a hot issuing 
period, there is reason to believe that excitement remained in the IPO market stemming from significant gains in 2014 and 2015.

\section{Findings}

Shake Shack had a first-day trading volume of over 16 million, much higher than its proceeding one-month average of 1.5 million. Additionally, the stock had a first day "pop" of 108.64 percent, making it one of the best IPOs of 2015. Given the growth opportunities of the company, Shake Shack is considered a Popular stock at the time of IPO. This should result in a high short-term return, followed by a long-term overpricing.

Figure 11.1 - Shake Shacks' Raw and Adjusted Returns January 30, 2015 - January 30,2020

\begin{tabular}{|c|c|c|c|}
\hline \multirow[t]{2}{*}{ Timeframe } & \multicolumn{3}{|c|}{ Return } \\
\hline & Raw & S\&P 500 & Adjusted \\
\hline $\begin{array}{l}\text { Date of IPO } \\
01 / 30 / 2015\end{array}$ & $108.64 \%$ & $-1.21 \%$ & $109.85 \%$ \\
\hline $\begin{array}{c}\text { One Month } \\
01 / 30 / 2015-02 / 30 / 2015\end{array}$ & $-5.99 \%$ & $5.50 \%$ & $-11.49 \%$ \\
\hline $\begin{array}{c}\text { One Year } \\
01 / 30 / 2015-01 / 30 / 2016\end{array}$ & $-24.66 \%$ & $-2.74 \%$ & $-21.92 \%$ \\
\hline $\begin{array}{c}\text { Three Years } \\
01 / 30 / 2015-01 / 30 / 2018\end{array}$ & $-5.47 \%$ & $41.48 \%$ & $-46.95 \%$ \\
\hline $\begin{array}{c}\text { Five Years } \\
01 / 30 / 2015-01 / 30 / 2020\end{array}$ & $48.37 \%$ & $64.08 \%$ & $-15.71 \%$ \\
\hline
\end{tabular}

As seen in figure 11.1, Shake Shack underperformed the S\&P 500 in the following four periods examined after its IPO. Even though the stock had gained 48.37 percent five years after it went public, Shake Shack's adjusted return was still lower than the 
benchmark S\&P 500. This is consistent with the Popularity concept, implying that investors were overconfident about Shake Shack's growth opportunities. 


\section{\#12 - Snap Inc. (SNAP)}

\section{Company Background}

In its 2017 prospectus, Snap Inc. describes itself as a camera company. It launched in 2011 as a social networking application. Snapchat is its flagship product, with 158 million daily active users (DAUs) and 2.5 billion Snaps sent every day (Snap Inc. 2017). In addition to their app, Snap also works to develop "Spectacles," which they view as the augmented reality glasses of the future. However, these are not a significant revenue stream at the time of the prospectus. Most of Snap's revenue is generated through advertising on the application. For the year ended December 31, 2016, Snap had revenue of $\$ 400$ million, with a net loss of $\$ 514$ million. While they were not profitable, the company detailed considerable growth opportunities for the future.

\section{Issuing Period}

By 2017 the markets were now nearly a decade removed from the financial crisis. After rough periods in 2015 and 2016, the IPO market appeared to be bouncing back in 2017. There were a total of 160 IPOs in 2017, led mainly by technology and biotechnology companies (Deagon 2017). Overall, 2017 was a hot issue period stemming from new excitement given the recovery in the IPO market.

\section{Findings}

Snap Inc. had a first-day trading volume of over 217 million, compared to a proceeding one-month average of about 47 million. Snap was a highly anticipated IPO with investors seeing what they missed out on with Facebook and wanting to reap the benefits. As a result, the stock price jumped 44 percent during its first day of trading. Snap Inc. was a 
Popular IPO given its first day "pop," along with the anticipation of its public offering. According to the Popularity concept, Snap should be overpriced in the long-term.

Figure 12.1 - Snap Inc's Raw and Adjusted Returns March 02, 2017 - March 02, 2020

\begin{tabular}{|c|c|c|c|}
\hline \multirow[t]{2}{*}{ Timeframe } & \multicolumn{3}{|c|}{ Return } \\
\hline & Raw & S\&P 500 & Adjusted \\
\hline $\begin{array}{c}\text { Date of IPO } \\
03 / 02 / 2017\end{array}$ & $44.00 \%$ & $-0.54 \%$ & $44.54 \%$ \\
\hline $\begin{array}{c}\text { One Month } \\
03 / 02 / 2017-04 / 02 / 2017\end{array}$ & $-7.97 \%$ & $-0.81 \%$ & $-7.16 \%$ \\
\hline $\begin{array}{c}\text { One Year } \\
03 / 02 / 2017-03 / 02 / 2018\end{array}$ & $-26.43 \%$ & $12.99 \%$ & $-39.42 \%$ \\
\hline $\begin{array}{c}\text { Three Years } \\
03 / 02 / 2017-03 / 02 / 2020\end{array}$ & $-41.22 \%$ & $24.03 \%$ & $-65.25 \%$ \\
\hline $\begin{array}{c}\text { Five Years } \\
03 / 02 / 2017-03 / 02 / 2022\end{array}$ & Null & Null & Null \\
\hline
\end{tabular}

Snap Inc's return is consistent with Popularity. As seen in figure 12.1, the company underperformed the benchmark in each of the following three periods examined since the IPO. Investors may have lost interest post-IPO, as Snapchat suffered consecutive periods of declining DAU growth. While figure $\mathbf{1 2 . 1}$ only has data for the first three years of Snap Inc., if consistent with Popularity, the company will remain below the benchmark return for the five years ending March 02, 2022. I hypothesize that this will be the case. 


\section{CONCLUSION}

Out of the twelve cases examined, seven were consistent with the Popularity concept. The dot com period had four Popular issuing firms, with two and three in the post dot com period and the app period, respectively. A total of nine IPOs studied were Popular, compared to three that were Unpopular. When aggregating the data, it appears that the Popular IPOs outperformed the Unpopular IPOs in each of the five periods examined, as shown in figure 13.1, compared to figure 13.2. However, further analysis of figure 13.1 shows that both AMZN and EBAY are significant outliers in the data, particularly in years three and five. As mentioned in the above cases, these are anomalistic companies, which led to the omittance of both issuing firms from figure 13.3.

Figure 13.1 - Popular Average S\&P 500 - Adjusted Returns

\begin{tabular}{|l|c|c|c|c|c|c|c|c|c|c|}
\hline & AMZN & EBAY & UPS & STMP & AXS & GOOG & TWTR & SHAK & SNAP & AVG \\
\hline $\begin{array}{l}\text { IPO } \\
\text { Date }\end{array}$ & $30.0 \%$ & $165 \%$ & $35.4 \%$ & $149 \%$ & $15.3 \%$ & $18.4 \%$ & $74.0 \%$ & $110 \%$ & $44.5 \%$ & $71 \%$ \\
\hline $\begin{array}{l}\text { One } \\
\text { Month }\end{array}$ & $-25.3 \%$ & $3.34 \%$ & $-5.63 \%$ & $219 \%$ & $-0.78 \%$ & $13.7 \%$ & $-3.21 \%$ & $-11.5 \%$ & $-7.2 \%$ & $20 \%$ \\
\hline $\begin{array}{l}\text { One } \\
\text { Year }\end{array}$ & $262 \%$ & $803 \%$ & $-16.0 \%$ & $-43.8 \%$ & $-6.50 \%$ & $167 \%$ & $-26.5 \%$ & $-21.9 \%$ & $-39 \%$ & $119 \%$ \\
\hline $\begin{array}{l}\text { Three } \\
\text { Years }\end{array}$ & $2,574 \%$ & $459 \%$ & $26.2 \%$ & $-42.8 \%$ & $-16.3 \%$ & $366 \%$ & $-82.0 \%$ & $-47.0 \%$ & $-65 \%$ & $352 \%$ \\
\hline $\begin{array}{l}\text { Five } \\
\text { Years }\end{array}$ & $734 \%$ & $1,305 \%$ & $35.7 \%$ & $-48.8 \%$ & $-14.2 \%$ & $352 \%$ & $-81.05 \%$ & $-15.7 \%$ & TBD & $283 \%$ \\
\hline
\end{tabular}

Figure 13.2 - Unpopular Average S\&P 500 - Adjusted Returns

\begin{tabular}{|l|c|c|c|c|}
\hline & NFLX & DPZ & FB & AVG \\
\hline $\begin{array}{l}\text { IPO } \\
\text { Date }\end{array}$ & $11.0 \%$ & $-3.50 \%$ & $1.37 \%$ & $2.95 \%$ \\
\hline
\end{tabular}




\begin{tabular}{|l|c|c|c|c|}
\hline $\begin{array}{l}\text { One } \\
\text { Month }\end{array}$ & $-9.41 \%$ & $3.77 \%$ & $-25.5 \%$ & $-10.4 \%$ \\
\hline $\begin{array}{l}\text { One } \\
\text { Year }\end{array}$ & $45.7 \%$ & $67.3 \%$ & $-60.1 \%$ & $17.7 \%$ \\
\hline $\begin{array}{l}\text { Three } \\
\text { Years }\end{array}$ & $75.1 \%$ & $0.8 \%$ & $47.2 \%$ & $41 \%$ \\
\hline $\begin{array}{l}\text { Five } \\
\text { Years }\end{array}$ & $133 \%$ & $-23.4 \%$ & $197 \%$ & $102 \%$ \\
\hline
\end{tabular}

Figure 13.3 - Popular Average S\&P 500 - Adjusted Returns, Null Outliers

\begin{tabular}{|l|c|c|c|c|c|c|c|c|}
\hline & UPS & STMP & AXS & GOOG & TWTR & SHAK & SNAP & AVG \\
\hline $\begin{array}{l}\text { IPO } \\
\text { Date }\end{array}$ & $35.4 \%$ & $149 \%$ & $15.3 \%$ & $18.4 \%$ & $74.0 \%$ & $110 \%$ & $44.5 \%$ & $63.8 \%$ \\
\hline $\begin{array}{l}\text { One } \\
\text { Month }\end{array}$ & $-5.63 \%$ & $219 \%$ & $-0.78 \%$ & $13.7 \%$ & $-3.21 \%$ & $-11.5 \%$ & $-7.2 \%$ & $29.2 \%$ \\
\hline $\begin{array}{l}\text { One } \\
\text { Year }\end{array}$ & $-16.0 \%$ & $-43.8 \%$ & $-6.50 \%$ & $167 \%$ & $-26.5 \%$ & $-21.9 \%$ & $-39 \%$ & $1.87 \%$ \\
\hline $\begin{array}{l}\text { Three } \\
\text { Years }\end{array}$ & $26.2 \%$ & $-42.8 \%$ & $-16.3 \%$ & $366 \%$ & $-82.0 \%$ & $-47.0 \%$ & $-65 \%$ & $19.8 \%$ \\
\hline $\begin{array}{l}\text { Five } \\
\text { Years }\end{array}$ & $35.7 \%$ & $-48.8 \%$ & $-14.2 \%$ & $352 \%$ & $-81.05 \%$ & $-15.7 \%$ & TBD & $38.0 \%$ \\
\hline
\end{tabular}

When adjusting for the outliers in figure 13.3, Popularity is apparent in the results. As shown graphically in figure 13.4, the Unpopular stocks produced a low first-day pop and a negative one-month return, followed by positive returns one year, three years, and five years post-IPO. On the contrary, Popular stocks have a high first-day pop, though fall lower in one month and one year returns. Then, they have an increased year three and year five return, albeit significantly lower than the unpopular stocks $(19.8 \%$ versus $41 \%$ and $38 \%$ versus $102 \%$ in years three and five, respectively). It is important to note that these are adjusted returns, so both the Popular and Unpopular IPOs significantly outperformed the broader S\&P 500 index. 


\section{Figure 13.4}

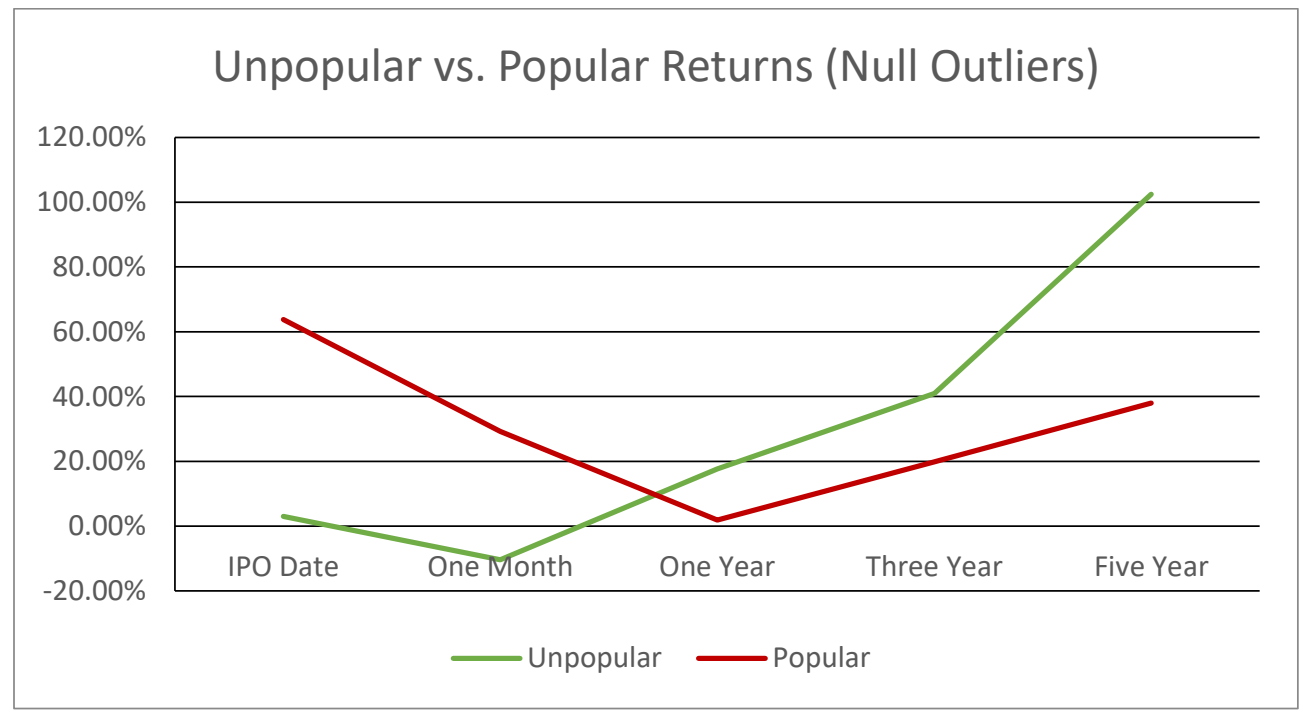

While the initial case study data lacks conclusiveness with only seven of twelve consistent with Popularity, evaluating the adjusted averages reveals that Popularity is apparent in the IPO market. However, it is essential to mention the shortcomings of this study, which include a minimal amount of cases (only three Unpopular) and the need to omit two out of twelve results. In future studies, it would be useful to evaluate longer-term returns. Additionally, a more qualitative set of Popularity characteristics in the IPO market may also increase the validity of this examination. 


\section{REFERENCES}

Alexander, Janet C. 1993. “Do the Merits Matter? A Study of Settlements in Securities Class Actions." Stanford Law Review. Vol. 43. No. 3. 497-598.

Amazon Com Inc. (1997). Form 424B1. https://d18rn0p25nwr6d.cloudfront.net/CIK0001018724/e5f6d0be-db89-4adb-8ba1-496ae09272cb.pdf

Amihud, Yakov and H. Mendelson. 1986. “Asset pricing and the bid-ask spread.” Journal of Financial Economics 17, pp. 223-249.

Baker, M., B. Bradley, and J. Wurgler. 2011. "Benchmarks as Limits to Arbitrage: Understanding the Low-Volatility Anomaly." Financial Analysts Journal, 67, pp. 4054.

Banz, Rolf W. 1981. “The Relationship between Returns and Market Value of Common Stocks." Journal of Financial Economics. Vol. 9, 3-18.

Benviste, Lawrence M., Paul A. Spindt. 1989. "How Investment Bankers Determine the Offer Price and Allocation of New Issues." Journal of Financial Economics. Vol. 24, No. 2. $343-361$.

Bhandari, Laxmi C. 1988. “Debt/Equity Ratio and Expected Common Stock Returns: Empirical Evidence." Journal of Finance Vol. 43, 507-528.

Black, Fischer, and Myron Scholes. 1973. "The Pricing of Options and Corporate Liabilities." Journal of Political Economy 81 (3): 637-54. 
Deagon, Brian. 2017. “U.S. IPO Market Makes Comeback in 2017 as Roku, Biotechs Thrive.” Investors. https://www.investors.com/news/technology/u-s-ipo-market-makescomeback-in-2017-as-roku-biotechs-thrive/

Domino's IPO Falls Below Offer Price. 2004. Forbes.

https://www.forbes.com/2004/07/13/0713automarketscan07.html\#791e7f7e378 3

Domino’s Pizza Inc. 2004. Form 424B1.

https://www.sec.gov/Archives/edgar/data/1286681/000119312504117543/d42 4b4.htm

Drake, Philip D., and Michael R. Vetsuypens. 1993. "IPO Underpricing and Insurance against Legal Liability." Journal of Financial Management. Vol. 22, No. 1. 64-73.

eBay Inc. 1998. Form S-1. https://content.edgaronline.com/ExternalLink/EDGAR/000101287098001814.html?hash=7e09f6a535b8676fc6bae63a2787a562107e1c73459ce559eb 28f680a563615a

Facebook Inc. 2012. Form 424B4. https://www.sec.gov/Archives/edgar/data/1326801/000119312512240111/d28 7954d424b4.htm

Fama, Eugene F. 1970. "Efficient Capital Markets: A Review of Theory and Empirical Work." Journal of Finance 25 (2): 383-417. 
Fama, Eugene F. and Kenneth R. French. 1992. "Common Risk Factors in the Returns on Stocks and Bonds." Journal of Financial Economics. Vol 33, 3-56.

Fama, Eugene F. and Kenneth R. French. 1996. "Multifactor Explanations of Asset Pricing Anomalies." Journal of Finance. Vol. 51, No. 1. 55-84.

Fama, Eugene and Kenneth French. 2004. "The Capital Asset Pricing Model: Theory and Evidence." Journal of Economic Perspectives. Vol 18, No. 3. 25-46.

Frayter, Karina. 2011. “Uncertainty Clouds 2012 IPO Market Outlook.” CNBC. https://www.cnbc.com/id/45568191

Gangloff, Mark. 2004. “IPOs Quietly Gathering Steam.” CNN Money. https://money.cnn.com/2004/09/29/markets/ipo/ipo_outlook/index.htm

Gelsi, Steve. 2002. “2002 IPO Market: It’s Like a Salad”. MarketWatch. https://www.marketwatch.com/story/ipo-market-starts-2002-with-a-salad

Google Inc. 2004. Form 424B4. https://www.sec.gov/Archives/edgar/data/1288776/000119312504143377/d42 4b4.htm

Harvey, Campbell R., and Akhtar Siddique. 2000. "Conditional Skewness in Asset Pricing Tests." Journal of Finance 55 (3): 1263-95.

Hong, Harrison, and Marcin Kacperczyk. 2009."The Price of Sin: The Effects of Social Norms on Markets." Journal of Financial Economics, pp. 15 - 36. 
Ibbotson, Roger G. 1975. “Price Performance of Common Stock News." Journal of Financial Economics. Vol. 3. 235-272.

Ibbotson, Roger G., Jeffrey F. Jaffe. (1975). “'Hot Issue' Markets." Journal of Finance. Vol. 30, No. 4.

Ibbotson, Roger G., Thomas M. Idzorek, Paul D. Kaplan, and James X. Xiong. 2018. “Popularity: A Bridge between Classical and Behavioral Finance." CFA Institute Research Foundation.

Ibbotson, Roger G., Jeffrey J. Diermeier, and Laurence B. Siegel. 1984. “The Demand for Capital Market Returns: A New Equilibrium Theory." Financial Analysts Journal 40 (1): 22-33.

Ibbotson, Roger G., and Thomas M. Idzorek. 2014. “Dimensions of Popularity.” Journal of Portfolio Management 40 (5), Special 40th Anniversary Issue: 68-74.

Ibbotson, Roger G., Jody L. Sindelar, and Jay R. Ritter. 1994. “The Market's Problems with the Pricing of Initial Public Offerings." Journal of Applied Corporate Finance. Vol. 7, No. 1. 66-74.

Idzorek, Thomas M., and Roger G. Ibbotson. 2017. "Popularity and Asset Pricing." Journal of Investing 26 (1): 46-56.

Keating, Tim. 2014. “2013: The IPO Year in Review.” Seeking Alpha. https://seekingalpha.com/article/1933201-2013-the-ipo-year-in-review

Kraus, A., and R. Litzenberger. 1976. "Skewness Preference and the Valuation of Risk Assets." Journal of Finance, 31, pp. 1085-1100. 
Lakonishok, Josef, Andrea Shleifer, and Robert W. Vishny. 1994. "Contrarian Investment, Extrapolation, and Risk." Journal of Finance, Vol. 49, No. 5. 1541 - 1578.

Ljungqvist, Alexander, William J. Wilhelm Jr. 2003. "IPO Pricing in the Dot-com bubble." Journal of Finance. Vol. 58, No. 2. 723-752.

Markowitz, Harry. 1959. "Portfolio Selection: Efficient Diversification of Investments." Cowles Foundation Monograph No. 16. New York: John Wiley \& Sons, Inc.

Muscarella, Chris., and Michael Vetsuypens 1989. "A Simple Test of Baron's Model of IPO Underpricing." Journal of Financial Economics. Vol. 24. 125-135.

Netflix Inc. 2002. Form 424B1.

https://www.sec.gov/Archives/edgar/data/1065280/000101287002002475/d42 4b4.htm

Renaissance Capital. 2016. "2015 US IPO Market Disappoints.” https://www.renaissancecapital.com/review/2015USReview.pdf

Ritter, Jay R. 1980. “The 'Hot Issue' Market of 1980.” Journal of Business. 215-240.

Ritter, Jay R. 2003. “Behavioral Finance”. Pacific-Basin Finance Journal. Vol. 11, No. 4. 429437

Ritter, Jay R. 1991. “The Long-Run Performance of Initial Public Offerings.” Journal of Finance. Vol. 46, No. 1. 3-27.

Rock, Kevin. 1985. “Why New Issues are Underpriced.” Journal of Financial Economics. Vol. 15. $187-212$. 
Shake Shack Inc. 2014. Form 424B4.

https://www.sec.gov/Archives/edgar/data/1620533/000104746914010114/a22 22577zs-1.htm

Sharpe, William F. 1964. "Capital Asset Prices: A Theory of Market Equilibrium under Conditions of Risk." Journal of Finance 19 (3): 425-42.

Shiller, Robert J. 1990. "Speculative Prices and Popular Models." Journal of Economic Perspectives. 55-65.

Shiller, Robert J. 2003. "From efficient markets theory to behavioral finance." Journal of Economic Perspectives, 17, 83-104.

Snap Inc. 2017. Form S-1. sec.gov/Archives/edgar/data/1564408/000119312517029199/d270216ds1.htm

Stamps.com. 1999. Form 424B4. https://investor.stamps.com/sec-filings/all-secfilings/content/0000944209-99-001025/0000944209-99-001025.pdf

Twitter Inc. 2013. Form 424B4. https://www.sec.gov/Archives/edgar/data/1418091/000119312513390321/d56 4001ds1.htm

United Parcel Service. 1999. Form 424B4. https://www.sec.gov/Archives/edgar/data/1090727/0000940180-99-001334.txt

Welch, Ivo. 1992. "Sequential Sales, Learning, and Cascades." Journal of Finance. Vol. 47, No. 2. 695-732. 
Westernberg, David A. 2004. “2003 IPO Market Finished Year on up Note - “. https://www.wilmerhale.com/en/insights/publications/2003-ipo-market-finishesyear-on-up-note-hale-and-dorr-announces-release-of-2003-ipo-report-february-102004

Weston, J. \& Gordon, Myron. 1963. The Investment, Financing and Valuation of the Corporation. The Journal of Finance. 18. 579. 


\section{APPENDIX}

\section{Appendix 1: Residual Return against Market Value}

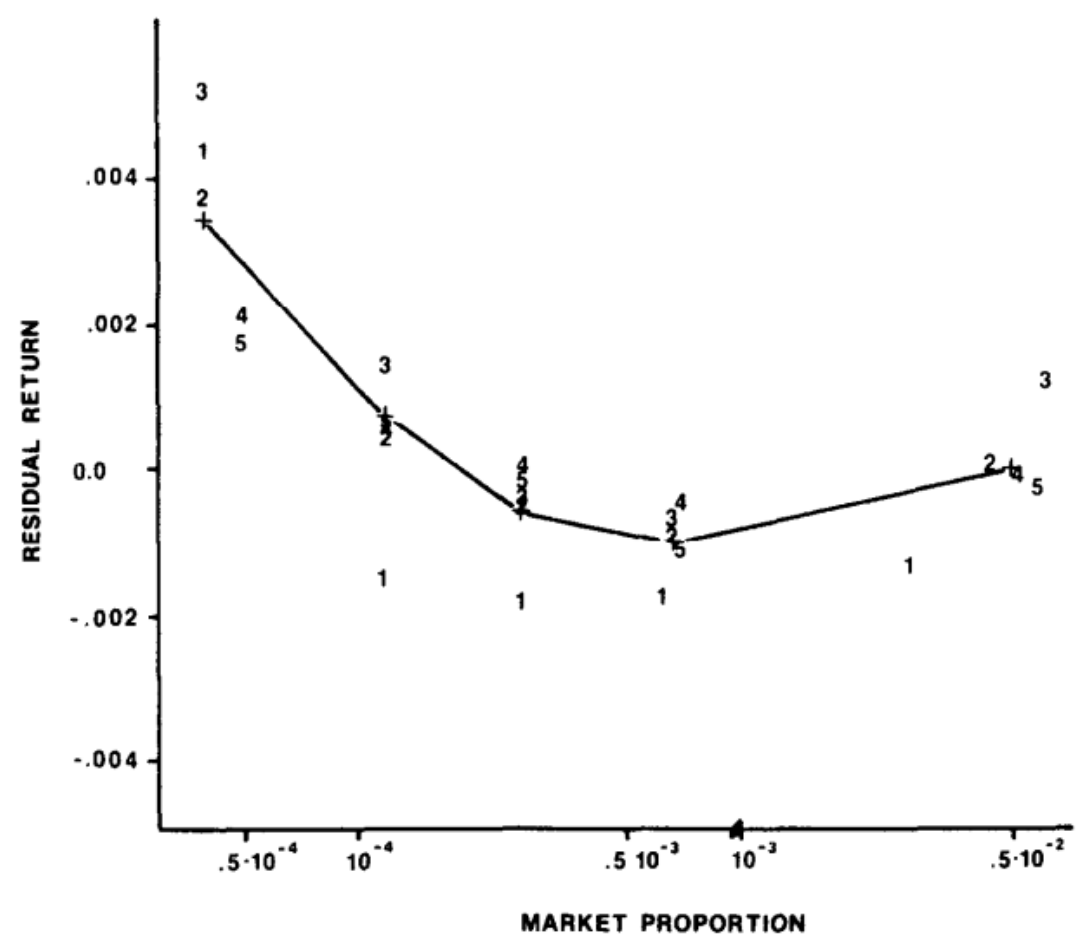

Fig. 1. Mean residual returns of portfolios (1936-1975) with equally-weighted CRSP index as market proxy. The residual is calculated with the three-factor model [eq. (3)]. The numbers $1, \ldots, 5$ represent the mean residual return for the five portfolios within each size group (1: portfolio with largest beta,. .,5. portfolıo with smallest beta) + represents the mean of the mean residuals of the five portfolios with similar market values. 
Appendix 2: Real Stock Prices and Present Values of Subsequent Real

Dividends (annual data)

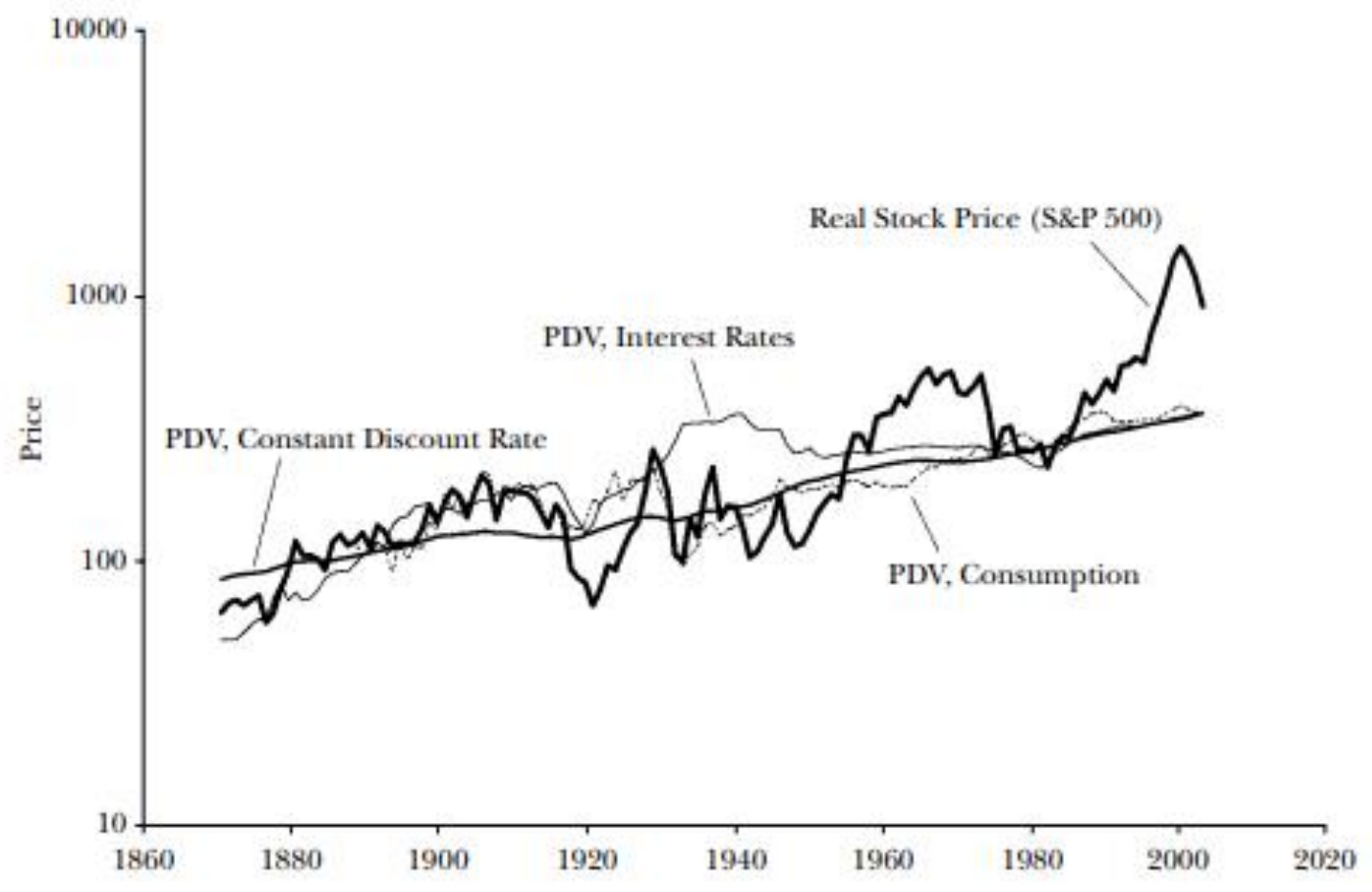




\section{Appendix 3: Popularity-Based Explanations of Premiums and Anomalies}

\section{Premium/Anomaly}

\section{Characteristic/}

\section{Dimension of}

\section{Popularity}

\section{Popularity based explanation}

\begin{tabular}{|c|c|}
\hline Equity Premium & Stocks are riskier than safe assets. Risk is unpopular. \\
\hline Size & $\begin{array}{l}\text { Small cap stocks are riskier than large cap stocks, as well as less liquid, less } \\
\text { well covered, and have lower investment "capacity." }\end{array}$ \\
\hline Value & $\begin{array}{l}\text { Value stocks are often out of favor (unpopular), less well known, and / or } \\
\text { operating in less glamorous industries. }\end{array}$ \\
\hline Liquidity & Investors prefer more liquidity to less. \\
\hline Risk Anomalies & $\begin{array}{l}\text { Severe Downside Risk: Investors dislike large losses. Low Vol/Beta: } \\
\text { Active managers prefer high beta stocks in hopes of outperforming } \\
\text { benchmarks. }\end{array}$ \\
\hline $\begin{array}{l}\text { Environmental, Social, } \\
\text { and Governance (ESG) }\end{array}$ & Investors avoid 'sin stocks' and seek out 'responsible' investments. \\
\hline $\begin{array}{l}\text { Competitive Advantage, } \\
\text { Brand, and Reputation }\end{array}$ & $\begin{array}{l}\text { Stocks with desirable attributes -- competitive advantage, brand power, or } \\
\text { firm reputation -- are sought out beyond their economic benefits. }\end{array}$ \\
\hline Momentum & $\begin{array}{l}\text { Attention causing event creates more interest, increases trading activity } \\
\text { and liquidity, resulting in an unsustainable virtuous mispricing cycle. }\end{array}$ \\
\hline
\end{tabular}

Source: Based on Exhibit 1 in Idzorek and Ibbotson (2017). 


\section{Appendix 4: Growth of \$1 for Equally Weighted Quartiles Based on}

Interbrand's BV Rankings, Åpril 2000 - August 2017 (log scale)

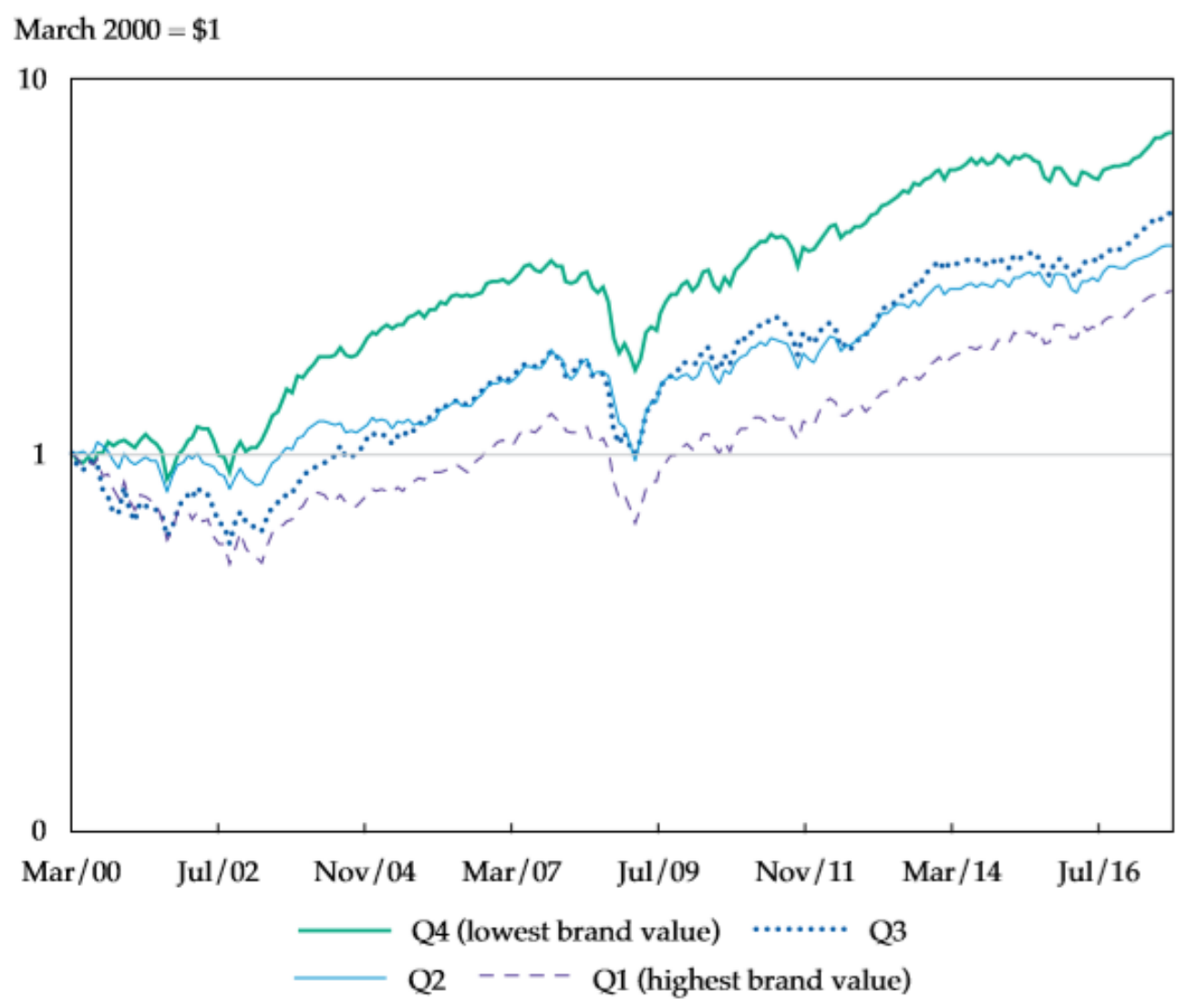

Source: Based on figure 6.1 in IIKX (2018) 
Appendix 5: Growth of \$1 for the Three Equally Weighted Portfolios Based on

Morningstar Economic Moat Ratings, July 2002 - August 2017 (log scale)

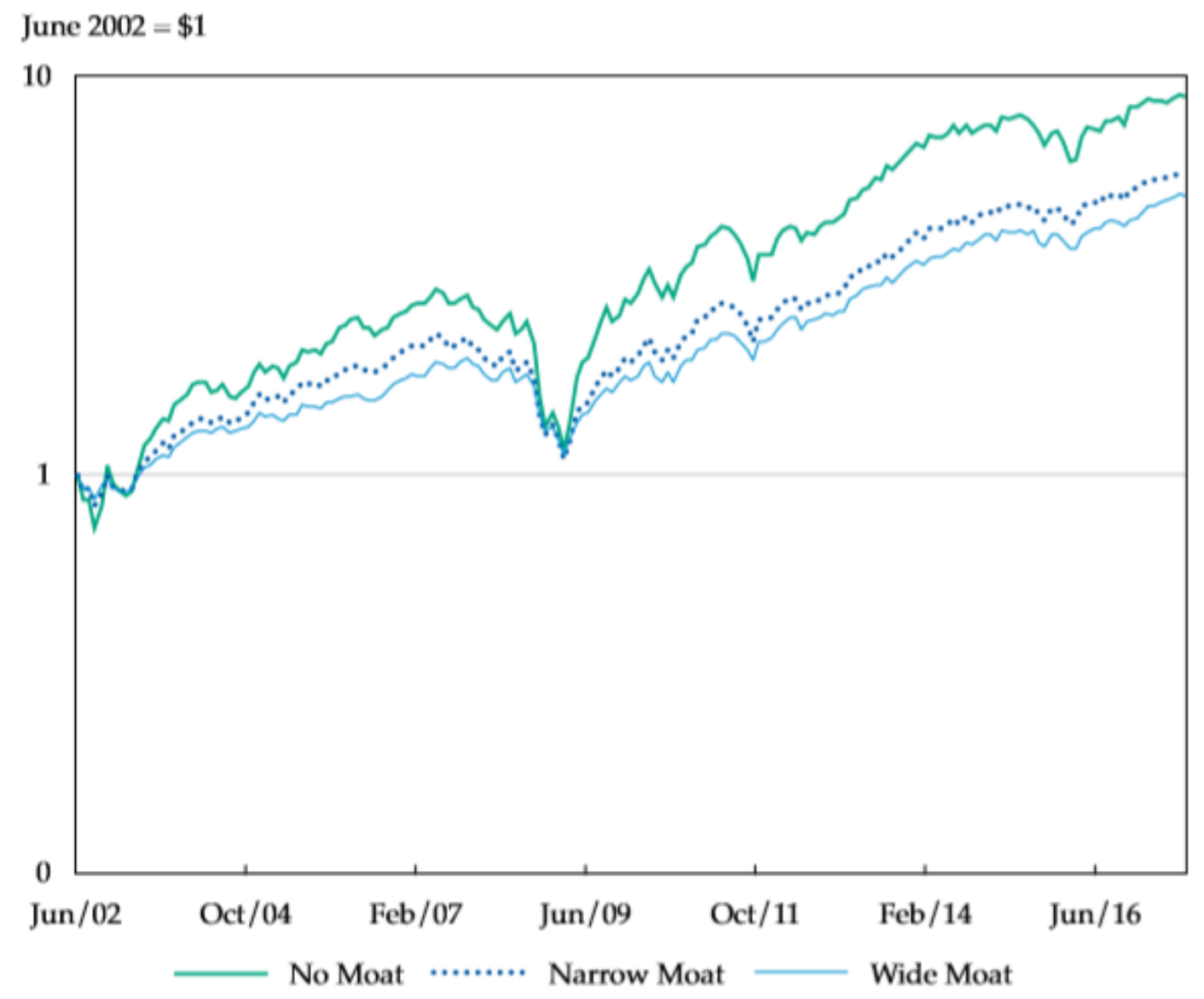

Source: Based on figure 6.3 in IIKX (2018). 
Appendix 6: Growth of \$1 for the Equally Weighted Quartile Portfolios Based on Harris Poll RQs, April 2000 - August 3028 (Log Scale)

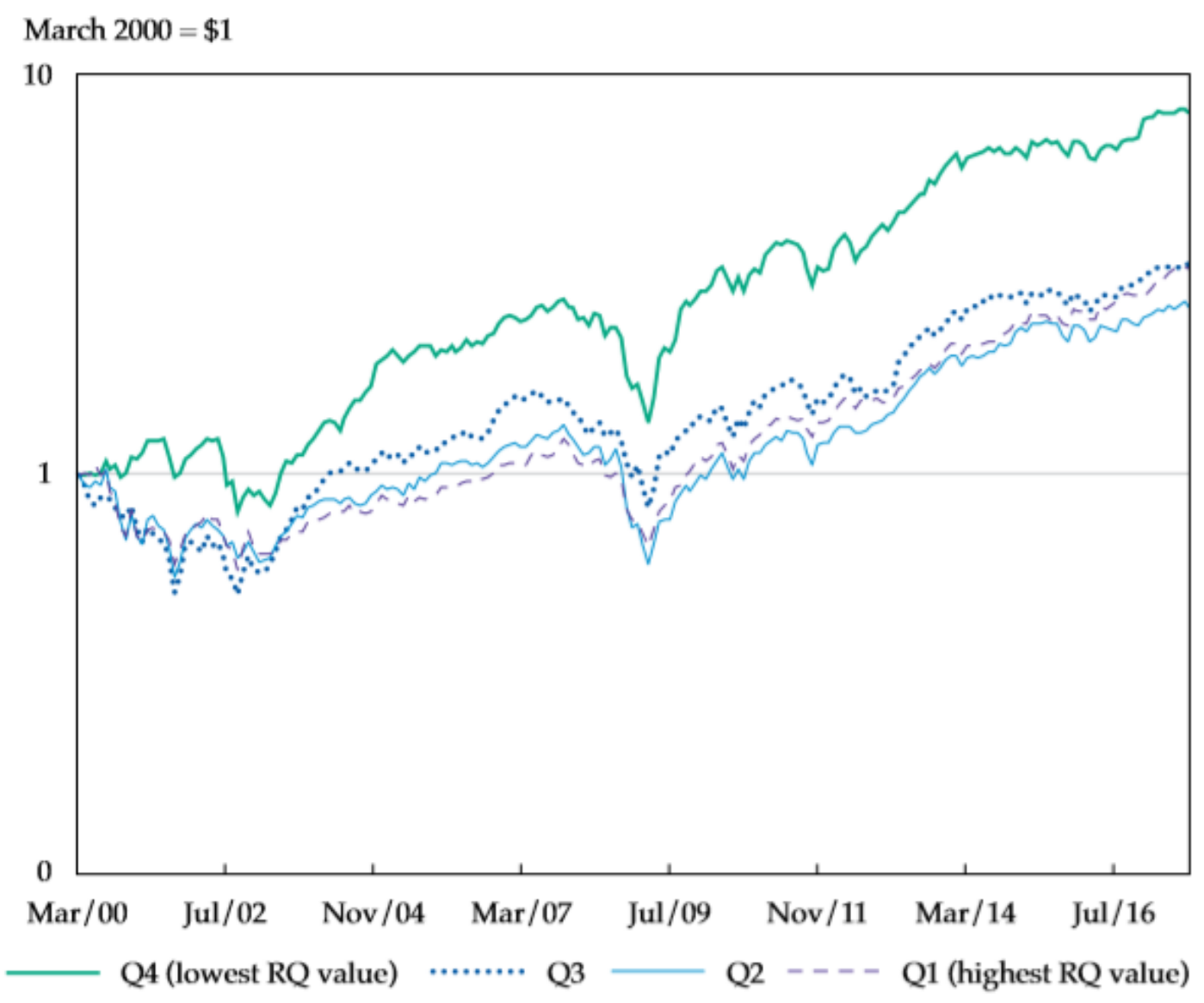

Source: Based on figure 6.4 in IIKX (2018). 


\section{Appendix 7: Growth of $\$ 1$ for Equally Weighted Quartile Portfolios Based on}

\section{Coskewness, January 1996 - August 2017 (log scale)}

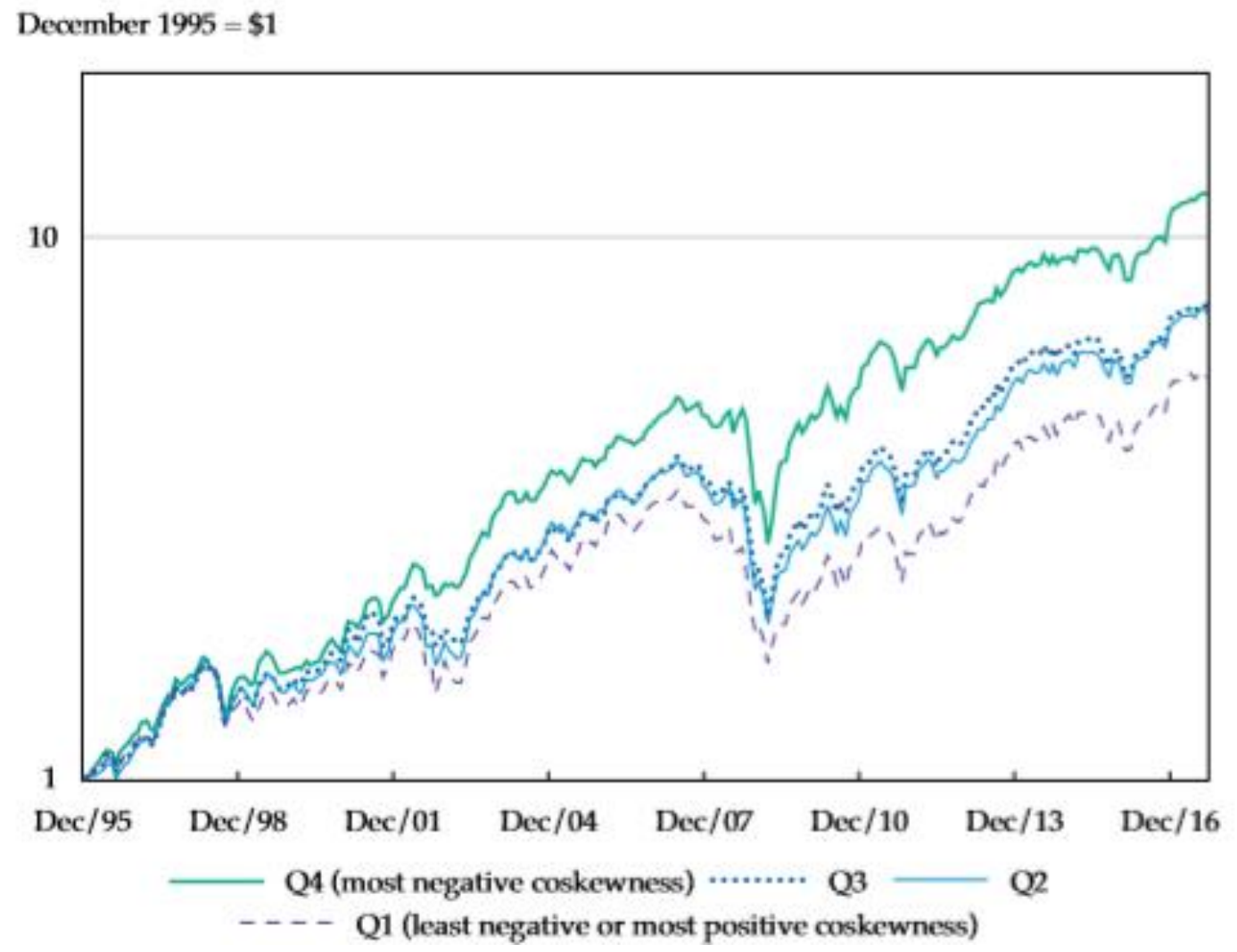

Source: Based on figure 6.5 in IIKX (2018). 